\title{
Proteomic analysis of acquired tamoxifen resistance in MCF-7 cells reveals expression signatures associated with enhanced migration
}

\author{
Changhua Zhou ${ }^{1,2}$, Qiu Zhong ${ }^{1,3}$, Lyndsay V Rhodes ${ }^{4}$, lan Townley ${ }^{3}$, Melyssa R Bratton 5 , Qiang Zhang ${ }^{3}$, \\ Elizabeth C Martin ${ }^{4}$, Steven Elliott ${ }^{4}$, Bridgette M Collins-Burow ${ }^{4}$, Matthew E Burow ${ }^{4,5}$ and Guangdi Wang ${ }^{1,3^{*}}$
}

\begin{abstract}
Introduction: Acquired tamoxifen resistance involves complex signaling events that are not yet fully understood. Successful therapeutic intervention to delay the onset of hormone resistance depends critically on mechanistic elucidation of viable molecular targets associated with hormone resistance. This study was undertaken to investigate the global proteomic alterations in a tamoxifen resistant MCF-7 breast cancer cell line obtained by long term treatment of the wild type MCF-7 cell line with 4-hydroxytamoxifen (4-OH Tam).

Methods: We cultured MCF-7 cells with 4-OH Tam over a period of 12 months to obtain the resistant cell line. A gel-free, quantitative proteomic method was used to identify and quantify the proteome of the resistant cell line. Nano-flow high-performance liquid chromatography coupled to high resolution Fourier transform mass spectrometry was used to analyze fractionated peptide mixtures that were isobarically labeled from the resistant and control cell lysates. Real time quantitative PCR and Western blots were used to verify selected proteomic changes. Lentiviral vector transduction was used to generate MCF-7 cells stably expressing S100P. Online pathway analysis was performed to assess proteomic signatures in tamoxifen resistance. Survival analysis was done to evaluate clinical relevance of altered proteomic expressions.
\end{abstract}

Results: Quantitative proteomic analysis revealed a wide breadth of signaling events during transition to acquired tamoxifen resistance. A total of 629 proteins were found significantly changed with 364 up-regulated and 265 down-regulated. Collectively, these changes demonstrated the suppressed state of estrogen receptor (ER) and ERregulated genes, activated survival signaling and increased migratory capacity of the resistant cell line. The protein S100P was found to play a critical role in conferring tamoxifen resistance and enhanced cell motility.

Conclusions: Our data demonstrate that the adaptive changes in the proteome of tamoxifen resistant breast cancer cells are characterized by down-regulated ER signaling, activation of alternative survival pathways, and enhanced cell motility through regulation of the actin cytoskeleton dynamics. Evidence also emerged that S100P mediates acquired tamoxifen resistance and migration capacity.

\section{Introduction}

Acquired resistance to hormone therapy remains a major challenge in the treatment of estrogen receptor positive $(\mathrm{ER}(+))$ metastatic breast cancers. Previous studies have demonstrated that ER (+) breast cancer can escape antiestrogen actions by up-regulating other signaling

\footnotetext{
* Correspondence: gwang@xula.edu

'Department of Chemistry, Xavier University of Louisiana, 1 Drexel Drive, New Orleans, LA 70125, USA

Full list of author information is available at the end of the article
}

pathways involved in cell survival and proliferation. Enhanced signaling via growth factor receptors, such as EGFR [1] and HER2 [2], has been implicated in acquired resistance to endocrine therapy. Activation of downstream intracellular signaling like the MAPK pathway and the PI3K/Akt pathway has also been linked to hormone resistance $[3,4]$. The cross-talk between ER and such alternative signaling pathways are believed to enable breast cancer to evade the antiproliferative effects of antiestrogens [5]. This knowledge has led to numerous

\section{Biomed Central}

(c) 2012 Zhou et al.; licensee BioMed Central Ltd. This is an open access article distributed under the terms of the Creative Commons Attribution License (http://creativecommons.org/licenses/by/2.0), which permits unrestricted use, distribution, and reproduction in any medium, provided the original work is properly cited. 
treatment strategies combining endocrine and targeted inhibitor therapies. However, early clinical trials of EGFR- and ERBB2-targeted inhibitors (for example, gefitinib, erlotinib, trastuzamab, and lapatinib) or m-TOR inhibitors (everolimus and temsirolimus) in combination with endocrine therapies have yielded mixed results [6-8]. It is likely that cross-talk and negative feedback loops may result in cellular resistance to individual inhibitors [9]. Additional therapies targeting converging points of shared signaling pathways, such as MYC and cyclin D1-CKD4, may be more effective at blocking proliferation in resistant breast cancers [10].

Current understanding of endocrine resistance mechanisms is largely based on the study of relatively few genes. Integrative approaches that examine gene expression in the genomic and proteomic context may lead to the discovery of previously unconsidered mechanisms for the modulation of therapeutic responses. The current study employed a quantitative proteomic strategy to capture global changes in protein expression in a tamoxifen resistant cell line derived from the wild type MCF-7 parental cells. In vitro studies of tamoxifen resistance have provided valuable foundational data that can be translated into in vivo and clinical applications [11-13]. The most widely used and best characterized cell line for study of acquired tamoxifen resistance has been the MCF-7 variants, from which much of our current understanding of the mechanisms of hormone resistance has derived $[13,14]$. While numerous earlier studies in other laboratories have demonstrated that tamoxifen resistant breast cancer cell lines were generated by long term exposure of MCF-7 cells to $10^{-6}$ to $10^{-7} \mathrm{M} 4-\mathrm{OH}$ Tam over a period of 6 to 12 months, adaptive signatures of the resulting resistant phenotypes may vary with different experimental conditions employed. For example, EGFR expression was reported to be 10-fold higher in one tamoxifen-resistant model [14] but not in other models $[15,16]$. It has also been shown [13] that use of dextran coated charcoal-stripped (DCC) serum in tamoxifen treatment may introduce, in addition to adaptive changes of the cells in response to tamoxifen, effects of long term estrogen deprivation (LTED), thus complicating the interpretation of molecular signals of resistance development for tamoxifen. Moreover, in estrogen deprived medium, tamoxifen can act as an agonist [17] towards $\mathrm{ER}$, adding another complicating factor to the mechanistic interpretation of tamoxifen resistance. We used a phenol-red free DMEM medium containing 5\% FBS so that the background estrogen level is in a range that is unlikely to induce adaptive changes due to estrogen deprivation and to minimize the agonistic action of tamoxifen in ER(+) breast cancer cells.

In this study, we examined global proteomic alterations of the tamoxifen resistant cell line vs the parental
MCF-7 cells using an isobaric labeling approach combined with a high resolution tandem mass spectrometry instrument for relative quantitative analysis. Our proteomics data demonstrated extensive adaptive changes in the proteome involving hundreds of significantly upand down-regulated proteins. In particular, results from this study revealed the overexpression of multiple tumorigenic, pro-metastatic proteins and the down-regulation of ER mediated signaling pathways. These findings provide novel insights into the complex events of the adaptive signaling network occurring during the acquisition of tamoxifen resistance in breast cancer cells and highlight the role of S100P in conferring both resistance and enhanced migration.

\section{Materials and methods}

\section{Cell culture}

MCF-7 cell line was purchased from ATCC (ATCC \#HTB-22, Manassas, VA, USA), and routinely cultured in phenol red-free DMEM medium supplemented with 5\% FBS, $4 \mathrm{mM}$ glutamine, $1 \mathrm{mM}$ sodium pyruvate, $100 \mathrm{IU} /$ $\mathrm{mL}$ penicillin, $100 \mu \mathrm{g} / \mathrm{mL}$ streptomycin and $0.25 \mu \mathrm{g} / \mathrm{mL}$ amphotericin. Tamoxifen resistant variant cells (MCF-7TamR) derived from MCF-7 cells were continuously cultured in the medium as described above containing additional $10^{-7} \mathrm{M}$ 4-OH Tam (Sigma-Aldrich, St Louis, MO, USA) for at least six months, along with the parental MCF-7-cells under identical culture conditions except that the control cells were treated with $0.1 \%$ ethanol. The two cell lines were grown side by side at all times. Cultures were maintained in 5\% carbon dioxide at a temperature of $37^{\circ} \mathrm{C}$.

\section{Cell growth assay}

For growth assay in the presence of $10^{-7} \mathrm{M} 4-\mathrm{OH}$ Tam, MCF-7 cells cultured with $10^{-7} \mathrm{M}$ 4-OH Tam for zero to six months were plated in six-well plates at a density of 50,000 in each well in 5\% FBS DMEM medium. The cells were then treated with $10^{-7} \mathrm{M}$ 4-OH Tam for five days, while equal treatment volumes of ethanol were used as a vehicle control. Cell numbers were counted with a Coulter instrument (Beckman-Coulter, Indianapolis, IN, USA). The ratio of 4-OH Tam treated cell numbers to vehicle treated cell numbers was defined as survival ratio. Experiments were conducted in triplicate and data represented as mean $\pm \mathrm{SD}$.

For dose-dependent proliferation assays, MCF-7-TamR and MCF-7-control cells were seeded in 96-well plate with a density 3,000 per well and treated with varying concentrations $\left(10^{-7}\right.$ to $\left.10^{-5} \mathrm{M}\right)$ of $4-\mathrm{OH}$ tamoxifen for five days; $0.1 \%$ ethanol was used as a vehicle control. Alamar Blue dye (Invitrogen, Grand Island, NY, USA) was added and incubated for $2 \mathrm{~h}$ at $37^{\circ} \mathrm{C}$, protected from light. A Synergy 2 microplate reader (BioTek, 
Winooski, VT, USA) was used to record fluorescence using an excitation wavelength at $560 \mathrm{~nm}$ and emission wavelength at $590 \mathrm{~nm}$. The ratio of 4-OH Tam-treated cell fluorescence intensity to that of vehicle treated cells was determined as the survival ratios in triplicate experiments. Data were represented as mean \pm SD.

\section{Colony formation assay}

Colony formation assays were conducted as outlined previously [18-20]. MCF-7-control or MCF-7-TamR cells were cultured in 5\% FBS phenol red-free DMEM. Cells were then plated at a density of 2,000 cells per well in $2 \mathrm{ml}$ 5\% FBS DMEM in six-well plates (Falcon, Franklin Lakes, NJ, USA) and allowed to adhere overnight at $37^{\circ} \mathrm{C}$, $5 \% \mathrm{CO}_{2}$. The next day cells were treated with 4-OH Tam $(100 \mathrm{nM})$. Equal treatment volumes of dimethyl sulfoxide (DMSO) were used as a vehicle control. Cells were allowed to grow until control treatment colonies reached $>50$ cells per colony (approximately 10 to 14 days). Colonies were then fixed with glutaraldehyde for 30 minutes, stained with crystal violet $(0.1 \%$ in $20 \%$ methanol) for 30 minutes and washed. Colony number was determined manually. Experiments were conducted in triplicate and data represented as mean \pm SEM.

\section{Cell lysis}

MCF-7-TamR and MCF-7-control cells were cultured to $80 \%$ confluent in the medium as described above, and washed with cold Hank's Buffered Salt Solution (HBSS) for three times, then collected with a cell scraper. NP40 cell lysis buffer (Invitrogen) containing additional $1 \mathrm{mM}$ of phenylmethylsulfonyl fluoride (PMSF) and protease inhibitor cocktail (Sigma) was used to extract total cellular proteins. The concentration of proteins was measured with BCA assay (Pierce Biotechnology, Rockford, IL, USA). The cell lysis was stored at $-80^{\circ} \mathrm{C}$ before further processing.

\section{Trypsin digestion}

Protein samples were digested with sequencing grade modified trypsin (Promega Corp. Madison, WI, USA) according to the manufacturer's instructions. Briefly, to aliquots of $100 \mu \mathrm{g}$ of protein sample was added $45 \mu \mathrm{L}$ of $200 \mathrm{mM}$ triethyl ammonium bicarbonate (TEAB) and the final volume was adjusted to $100 \mu \mathrm{L}$ with ultrapure water. A total of $5 \mu \mathrm{L}$ of $200 \mathrm{mM}$ tris(2-carboxyethyl) phosphine (TCEP) was added and the resulting mixture was incubated for $1 \mathrm{~h}$, then $5 \mu \mathrm{L}$ of $375 \mathrm{mM}$ iodoacetamide was added and the mixture was incubated for 30 minutes without light. After incubation, $1 \mathrm{~mL}$ of prechilled acetone was added and the precipitation was allowed to proceed overnight. The acetone-precipitated protein pellets were suspended with $100 \mu \mathrm{L}$ of $200 \mathrm{mM}$
TEAB and $2.5 \mu \mathrm{g}$ of trypsin was added to digest the sample overnight at $37^{\circ} \mathrm{C}$.

\section{Tandem Mass Tags (TMT) labeling}

Tandem mass tags TMT $^{6}$ (Thermo Scientific, Rockford, IL, USA) with different molecular weights (126 to approximately $131 \mathrm{Da}$ ) were applied as isobaric tags for relative and absolute quantification. According to the manufacturer's protocols, the digested samples were individually labeled with $\mathrm{TMT}^{6}$ reagents for $1 \mathrm{~h}$ as follows: three 100- $\mu \mathrm{g}$ aliquots of digested MCF-7-control peptides were each labeled with a different isobaric tag

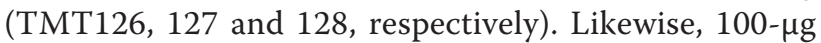
aliquots of peptides from MCF-7-TamR cells were labeled with TMT129, 130, and 131 mass tags, respectively. The labeling reaction was quenched with $5 \%$ hydroxylamine. Finally, the six labeled peptide aliquots were combined for subsequent fractionation.

\section{Fractionation of labeled peptide mixture using a strong cation exchange column}

The combined TMT labeled peptide mixture was fractionated with a strong cation exchange column (SCX) (Thermo Scientific) on a Shimadzu 2010 HPLC equipped with a UV detector (Shimadzu, Columbus, MD, USA). Mobile phase consists of buffer A (5 mM $\mathrm{KH}_{2} \mathrm{PO}_{4}, 25 \%$ acetonitrile, $\mathrm{pH} 2.8$ ) and buffer B (buffer A plus $350 \mathrm{mM} \mathrm{KCl}$ ). The column was equilibrated with Buffer A for 30 minutes before sample injection. The mobile phase gradient was set as follows at a flow rate of $1.0 \mathrm{~mL} /$ minute: (a) 0 to 10 minutes: $0 \%$ buffer B; (b) 10 to 40 minutes: $0 \%$ to $25 \%$ Buffer B, (c) 40 to 45 minutes: $25 \%$ to $100 \%$ Buffer B; (d) 45 to 50 minutes: $100 \%$ buffer B; (e) 50 to 60 minutes: $100 \%$ to $0 \%$ buffer B; (f) 60 minutes to 90 minutes: $0 \%$ buffer B. A total of 60 fractions were initially collected, lyophilized and combined into 15 final fractions based on SCX chromatographic peaks.

\section{Desalination of fractionated samples}

A $\mathrm{C}_{18}$ solid-phase extraction (SPE) column (Hyper-Sep SPE Columns, Thermo-Fisher Scientific, Waltham, MA, USA) was used to desalt all collected fractions. The combined 15 fractions were each adjusted to $1-\mathrm{mL}$ final volume containing $0.25 \%$ (v/v in water) trifluoroacetic acid (TFA, Sigma). The $\mathrm{C}_{18}$ SPE columns were conditioned before use by filling them with $1 \mathrm{~mL}$ acetonitrile and allowing the solvent to pass through the column slowly (approximately three minutes). The columns were then rinsed three times with $1 \mathrm{~mL} 0.25 \%$ (v/v in water) TFA solution. The fractions were loaded on to the top of the SPE cartridge and allowed to elute slowly. Columns were washed four times with 1-mL $0.25 \%$ TFA aliquots before 
the peptides were eluted with $3 \times 400 \mu \mathrm{L}$ of $80 \%$ acetonitrile/0.1\% formic acid (aqueous).

\section{LC-MS/MS analysis on LTQ-Orbitrap}

Peptides were analyzed on an LTQ-Orbitrap XL instrument (Thermo-Fisher Scientific) coupled to an Ultimate 3000 Dionex nanoflow LC system (Dionex, Sunnyvale, CA, USA). High mass resolution was used for peptide identification and high energy collision dissociation (HCD) was employed for reporter ion quantification. The RP-LC system consisted of a peptide Cap-Trap cartridge $(0.5 \times 2 \mathrm{~mm})$ (Michrom BioResources, Auburn, CA, USA) and a pre-packed BioBasic $\mathrm{C}_{18}$ PicoFrit analytical column $(75 \mu \mathrm{m}$ i.d. $\times 15 \mathrm{~cm}$ length, New Objective, Woburn, MA, USA) fitted with a FortisTip emitter tip. Samples were loaded onto the trap cartridge and washed with mobile phase A $\left(98 \% \mathrm{H}_{2} \mathrm{O}, 2 \%\right.$ acetonitrile and $0.1 \%$ formic acid) for concentration and desalting. Subsequently, peptides were eluted over 180 minutes from the analytical column via the trap cartridge using a linear gradient of 6 to $100 \%$ mobile phase $\mathrm{B}\left(20 \% \mathrm{H}_{2} \mathrm{O}\right.$, $80 \%$ acetonitrile and $0.1 \%$ formic acid) at a flow-rate of $0.3 \mu \mathrm{L} /$ minute using the following gradient: $6 \% \mathrm{~B}$ for 5 minutes; 6 to $60 \%$ B for 125 minutes; 60 to $100 \% \mathrm{~B}$ for 5 minutes; hold at $100 \%$ B for 5 minutes; 100 to $6 \%$ $\mathrm{B}$ in 2 minutes; hold at $6 \% \mathrm{~B}$ for 38 minutes.

The LTQ-Orbitrap tandem mass spectrometer was operated in a data-dependent mode. Briefly, each full MS scan (60,000 resolving power) was followed by six MS/MS scans where the three most abundant molecular ions were dynamically selected and fragmented by collision-induced dissociation (CID) using a normalized collision energy of $35 \%$, and the same three molecular ions were also scanned three times by $\mathrm{HCD}-\mathrm{MS}^{2}$ with collision energy of $45 \%$. MS scans were acquired in profile mode and MS/MS scans in centroid mode. LTQ-Orbitrap settings were as follows: spray voltage $2.0 \mathrm{kV}$, 1 microscan for MS1 scans at 60, 000 resolution (fwhm at $m / z 400)$, microscans for $\mathrm{MS}^{2}$ at 7,500 resolution (fwhm at $m / z 400$ ); full MS mass range, $m / z 400$ to 1,400; MS/MS mass range, $m / z 100$ to 2,000. The "FT master scan preview mode", "Charge state screening", "Monoisotopic precursor selection", and "Charge state rejection" were enabled so that only the $2+, 3+$ and $4+$ ions were selected and fragmented by CID and HCD.

\section{Database search and TMT quantification}

The protein search algorithm used was Mascot (Matrix Science, Boston, MA, USA). Mascot format files were generated by the Proteome Discoverer 1.2 software (Thermo-Fisher Scientific) using the following criteria: database, IPI_Human.fasta.v3.77; enzyme, trypsin; maximum missed cleavages, 2; Static modifications, carbamidomethylation (+57 Da), N-terminal TMT6plex (+229
Da), lysyl TMT6plex (+229 Da). Dynamic modifications, N-terminal Cln- pyro-Glu(+17Da); methionine oxidation (+16 Da); STY phosphorylation (+80 Da); MS peptide tolerance was set at $15 \mathrm{ppm}$; MS/MS tolerance at $0.05 \mathrm{Da}$. Peptides reported by the search engine were accepted only if they met the false discovery rate of $P<$ 0.05 (target decoy database). For TMT quantification, the ratios of TMT reporter ion abundances in MS/MS spectra generated by HCD (up to six reporter ions ranging from $m / z 126.12$ to $\mathrm{m} / \mathrm{z} 131.14$ ) from raw data sets were used to calculate fold changes in proteins between control and treatment.

\section{Quantitative RT-PCR \\ Confirmation of selected targets identified in proteomic analysis}

Total RNA from MCF-7-TamR and control cells was extracted using a PureLink total RNA purification system (Invitrogen) and quantitatively analyzed with a nanodrop spectrophotometer (Thermo Scientific). The reverse transcription was carried out with a SuperScript first-strand synthesis system (Invitrogen) using Oligo $(\mathrm{dT})_{12-18}$ primers. The primer pairs used to amplify the genes were designed using the online tool of Oligo Perfect Designer (Invitrogen), and beta actin (actb) was employed as an internal standard. Primer specificity was confirmed by BLAST analysis. For real-time PCR analyses, a MyiQ real time PCR detection system (BioRad, Hercules, CA, USA) and a SYBR GreenER qPCR supermix kit (Invitrogen) were used as follows: $50^{\circ} \mathrm{C}$ for 2 minutes, $95^{\circ} \mathrm{C}$ for 8 minutes and 30 seconds, and 50 cycles $\left(15\right.$ seconds at $95^{\circ} \mathrm{C}, 1$ minute at $60^{\circ} \mathrm{C}$ ). The data were analyzed with a normalized gene expression method $(\Delta \Delta \mathrm{Ct})$ using the iQ5 Optical System Software (BioRad), and the gene actb was used as a reference for normalization. All experiments were repeated three times independently.

\section{$E R$ regulated gene transcripts}

MCF-7-control or MCF-7-TamR cells were seeded at a density of $2 \times 10^{6}$ cells per $25 \mathrm{~cm}^{2}$ culture flask in phenol red-free 5\% FBS-DMEM. On the following day, cells were washed in PBS and media were changed to phenol red-free media supplemented with $5 \%$ CSDMEM and grown to 50 to $80 \%$ confluency for $48 \mathrm{~h}$ before treatment with vehicle (DMSO), $17 \beta$-estradiol (100 pM), or tamoxifen (100 nM). RNA was extracted using QiaShredders (QIAGEN, Valencia, CA, USA) and purified on RNeasy columns (QIAGEN) according to the manufacturer's protocol. RNA quality and concentration were determined by absorbance at 260 and $280 \mathrm{~nm}$. Then $2 \mu \mathrm{g}$ of total RNA was reverse transcribed using the iScript kit (Bio-Rad Laboratories). The levels of ER $\alpha$, PgR and SDF-1 transcripts were determined using real-time quantitative PCR. The primer sequences are as follows (sense and antisense, 
respectively): PgR, 5'-TACCCGCCCTATCTCAACT ACC-3', 5'-TGCTTCATCCCCACAG-ATTAAACA-3'; SDF-1, 5'-AGTCAGGTGGTGGCTTAACAG-3', 5'-AG AGGAGGTGAAGGCAGTGG-3'; and $\mathrm{ER}_{\alpha}, 5^{\prime}$-GGCA TGGTGGAGATCTTCGA-3', 5'-CCTCTCCCTGCAGATTCATCA-3', Actin, 5'- TGA GCG CGG CTA CAG CTT -3', 5'-CCTTAATGTCACACACGATT-3'. The PCR reaction was carried out as follows: step 1 : $95^{\circ} \mathrm{C} 3$ minutes; step 2: for 40 cycles $95^{\circ} \mathrm{C} 20$ seconds, $60^{\circ} \mathrm{C} 1$ minute; step 3: $70^{\circ} \mathrm{C} 10$ seconds, held at $4^{\circ} \mathrm{C}$. Each reaction tube contained: $12.5 \mu \mathrm{L} 2 \times$ SYBR Green supermix $+6.5 \mu \mathrm{L}$ nuclease-free water $+1 \mu \mathrm{L} 0.1 \mu \mathrm{g} /$ $\mu \mathrm{L}$ primer (pair) $+5 \mu \mathrm{L}$ cDNA $(0.2 \mu \mathrm{g} / \mu \mathrm{L})$. Genes were amplified in triplicate. Data were analyzed by comparing relative target gene expression to actin control. Relative gene expression was analyzed using 2- $\Delta \Delta$ Ct method [21].

\section{Western blot}

MCF-7-control or MCF-7-TamR cells were seeded in $10 \mathrm{~cm}^{2}$ plates at a density of 60 to $70 \%$ confluence ( 5 to $10 \times 10^{6}$ cells) and were allowed to grow for three days until they approached 80 to $90 \%$ confluence. The media was then removed and the cells were scraped into $1 \mathrm{~mL}$ of PBS plus $3 \mathrm{mM}$ EDTA. The cell suspensions were spun for five minutes at $2,000 \times \mathrm{g}$ and the supernatant was aspirated. The cell pellets were lysed by vortexing in $200 \mu \mathrm{L}$ of M-PER mammalian protein extraction buffer (Pierce, cat. \# 78501) containing protease and phosphatase inhibitors (Sigma, cat. \#'s P1860-1ML, P0044, and P5726). The samples were then spun in a microcentrifuge for five minutes at $12,000 \times \mathrm{g}$ and the supernatants were collected. Protein concentrations were determined using a nanodrop spectrophotometer (Thermo Life Sciences) and $50 \mu \mathrm{g}$ of total protein was loaded and run on a 4 to $12 \%$ polyacrylamide gel (Invitrogen). The gels were blotted onto nitrocellulose using the iblot transfer system (Invitrogen). The blots were blocked for one hour at room temperature in $1 \times$ TBST (Affymetrix, Santa Clara, CA, USA, cat \# 775005 LT) containing 5\% non-fat milk. The blots were then washed in $1 \times$ TBST and were incubated overnight at $4^{\circ} \mathrm{C}$ in $10 \mathrm{~mL}$ of primary antibody at a 1:500 dilution in 5\% BSA/TBST (Sigma cat \# A7906-1 $\mathrm{KG})$. Blots were then washed in $1 \times$ TBST and incubated with infrared-labeled secondary antibodies (LiCor) for 30 minutes at room temperature. The blots were then washed in $1 \times$ TBST and scanned using the Odyssey infrared imaging system (LiCor, Lincoln, NE USA). Bands were quantified using the Odyssey software (LiCor) and normalized to bands corresponding to the housekeeping Rho-GDI protein. Four independent samples were prepared for each cell line. Paired $t$ test analyses were performed for each protein using Origin 8.5.1 software (control vs TamR), and $P$-values $<0.05$ were considered significant.

\section{Transwell migration assay}

Migration assays were performed following the manufacturer's instructions (BD Falcon, Sparks, MD, USA). Briefly, MCF-7-control or MCF-7-TamR cells were seeded at a density of $2.5 \times 10^{4}$ in $500 \mu \mathrm{L}$ serum-free and phenol redfree media in the upper chamber of a 24-well transwell system. Phenol red-free DMEM supplemented with FBS (5\%) was used as a chemoattractant in the lower wells. After $24 \mathrm{~h}$, membranes were scrubbed, fixed with $10 \%$ phospho-buffered formalin, permeabilized with $100 \%$ icecold methanol, and stained with $0.1 \%$ crystal violet in $20 \%$ methanol. Membranes were removed and mounted on glass slides for visualization by light microscopy. Data are represented as a percent of the migrated MCF-TamR cells per $100 \times$ field of view $(100 \times) \pm$ SEM for triplicate experiments.

\section{MCF-7 cells overexpressing S100P \\ Construction of S100P lentiviral vector}

The S100P gene was generated by elongating RT-PCR using a Superscript III one-step RT-PCR system (Invitrogen) with the following primers: S100P-F (sense) 5'-CGC CAC CAT GAC GGA ACT AGA GAC AGC C-3' and S100P-R (antisense) 5'-GGA TCC TCA TTT GAG TCC TGC CTT CTC-3'. The RT-PCR reaction was carried out as follows: step $1: 45^{\circ} \mathrm{C}$ for 30 minutes and $94^{\circ} \mathrm{C}$ for 2 minutes; step 2: 35 cycles at $94^{\circ} \mathrm{C}$ for $15 \mathrm{sec}, 51^{\circ} \mathrm{C}$ for $30 \mathrm{sec}$ and $72^{\circ} \mathrm{C}$ for 1 minute; step $3: 72^{\circ} \mathrm{C}$ for 5 minutes and held at $4^{\circ} \mathrm{C}$. The PCR product was cloned using a TA Cloning kit (Invitrogen). The S100P lentiviral vector (pLenti6/S100P) was constructed by digesting vector pLenti6 (Invitrogen) with EcoR I and BamH I for insertion of the S100P gene.

\section{MCF-7-S100P cell line stably overexpressing S100P}

To produce S100P-overexpressing lentivirus, the 293FT cells were co-transfected with expression construct (pLenti6/S100P) and the optimized packaging mix (ViraPower Packaging mix, Invitrogen) from a lentiviral expression system (Invitrogen). The transfection was carried out by incubating cells overnight at $37^{\circ} \mathrm{C}$ in a $\mathrm{CO}_{2}$ incubator using a Lipofectamine 2000 reagent (Invitrogen). Media were replaced in 24 hours and the virus-containing supernatants were harvested and centrifuged at 48 to 72 hours. MCF-7 cells were grown to 30 to $50 \%$ confluent, and the culture medium was replaced with viral supernatants as obtained previously. Polybrene was added for the overnight viral transfection. Subsequently, medium was replaced every 2 to 3 days with antibiotic (Blasticidin) and the selection process continued for a total of 10 to 12 days. The stable MCF-7-S100P cell line was cultured in 
phenol red free DMEM medium with 5\% FBS, and the S100P expression was checked with Western blot.

\section{Bioinformatics and statistics}

Bioinformatics were performed on significantly altered proteins. This was determined by two parameters: one is having an analytical replication $P$-value of $<0.05$ and the second is determined by the ratio value. The standard deviation (SD) of all the ratios in the control sample was determined and then significance was defined as $(1+/$ 2SD) [22-24]. Classification of proteins was determined by the web program PANTHER [25]. The proteins were analyzed for over expression of gene ontology terms in the categories of pathways, molecular function and biological process. Pathway mapping was done using Pathvisio 2.0.11, a tool for visualizing and editing biological pathways [26]. The ratio data of the significant proteins were loaded into Pathvisio and used to map onto preloaded pathways from Wikipathways [27] and KEGG [28-30]. The pathway thus created was heavily modified from KEGG pathway 04810, "Regulation of actin cytoskeleton" in Homo sapiens.

\section{Patient survival analysis}

An online database [31] was used to assess relevance of significantly changed protein expressions to relapse-free survival. The database was established using gene expression data and survival information on 1,809 patients downloaded from Gene Expression Omnibus (GEO) (Affymetrix HGU133A and HGU133+2 microarrays, Santa Clara, CA, USA). Briefly, single or multiple genes were entered into the database to obtain Kaplan-Meier survival plot where the number-at-risk was indicated below the main plot. Hazard ratio (and 95\% confidence intervals) and $\log$ rank $P$ were calculated and displayed on the webpage. For the genes listed in Tables 1 and 2, their effects on relapse-free survival (RFS) were calculated and listed. Positive logrank $P$-values indicate positive correlation (that is, either overexpression or down-regulation of a gene correlates with decreased survival) and negative logrank $P$-values indicate negative correlation (that is, either up- or down-regulation of a gene is associated with increased survival).

\section{Results \\ Establishment of 4-hydroxytamoxifen resistant cell line, MCF-7-TamR}

Cell growth assays were performed to determine the acquired resistance of MCF-7 cells in response to continuous exposure to 4-hydroxytamoxifen over a period of six months. Initially, MCF-7 cells showed greater than 50\% growth inhibition with tamoxifen treatment as measured by survival ratio. As shown in Figure 1A, the survival ratio of the tamoxifen-treated MCF-7 cells was approximately
$45 \%$. By the end of the first month, the ratio reached $75 \%$. The survival ratio increased further to $90 \%$ by the end of month 2 , indicating that tamoxifen-treated cells have resumed the growth rate comparable to untreated conditions. The survival ratio of the tamoxifen treated cell line remained at about $90 \%$ from month 3 and beyond.

The acquired resistance to tamoxifen was further measured by dose-dependent growth assays (Figure 1B). When both MCF-7-control and MCF-7-TamR cells were treated with 4-OH Tam at increasing concentrations from $10^{-7} \mathrm{M}$ to $10^{-5} \mathrm{M}$, the survival ratios showed marked differences between the two cell lines. For instance, at $100 \mathrm{nM} 4-\mathrm{OH}$ Tam, MCF-7-TamR cells maintained a 90\% survival ratio, compared to $60 \%$ for the tamoxifen sensitive MCF-7-control cells. At $4 \mu \mathrm{M}$, the ratio dramatically decreased to $30 \%$ for the control cells but remained around $70 \%$ for MCF-7-TamR. This trend continued until 4-OH Tam concentration reached $10 \mu \mathrm{M}$ where no cells survived from either cell line (Figure 1B).

To further investigate the proliferative behavior of the resistant cell line clonogenic assays were also performed. MCF-7-control and MCF-7-TamR cells were each treated with vehicle (DMSO) or $100 \mathrm{nM} 4-\mathrm{OH}$ Tam. The proliferation of tamoxifen sensitive MCF-7 cells was significantly inhibited in the presence of $100 \mathrm{nM}$ 4-OH Tam (approximately 400 colonies compared to 720 in DMSO, Figure 2A). In contrast, the MCF-7-TamR cells demonstrated strong resistance to 4-OH Tam induced inhibition of colony formation. Shown in Figure 2B is a representative image of colony formation of the two cell lines treated with vehicle (DMSO) and 4-OH Tam, respectively.

\section{Proteomics data reveal extensive changes in expression associated with acquired tamoxifen resistance}

To increase the total number of proteins that can be identified and quantified in whole cell lysates, we used a gel-free approach that relies on isobaric mass tag labeling for quantitative analysis and a combination of twodimensional HPLC separation and high resolution mass spectrometry for maximal peptide detection and identification. Indeed, this approach yielded a total of 2,128 identified and 2,088 quantified proteins, which represent five to six times more proteins than were analyzed by a 2D-gel based approach used in our previous study [32]. Of these proteins, over 1,200 were found to have statistically significant changes $(P<0.05)$ in expression in the tamoxifen resistant cell line (Additional file 1 Table S1). While this number appears high, it reflects the high confidence in the analytical reproducibility because the $P$-values were calculated from the three isobaric labels as analytical replicates for each cell line sample. Thus, some of the smaller fold changes in protein expression, while statistically significant and accurately reflective of the 
Table 1 Selected up-regulated proteins in tamoxifen resistant breast cancer cells

\begin{tabular}{|c|c|c|c|c|c|c|c|}
\hline Accession & $\begin{array}{l}\# \\
\text { AAs }\end{array}$ & $\begin{array}{l}\mathrm{MW} \\
(\mathrm{kDa})\end{array}$ & Description & $\begin{array}{l}\text { Gene } \\
\text { symbols }\end{array}$ & $\begin{array}{l}\text { Fold change } \\
\text { TamR/Ctrl }\end{array}$ & $\begin{array}{l}\mathrm{t} \text {-test } \\
(P \text { - } \\
\text { values })\end{array}$ & $\begin{array}{l}\text { Relapse free survival analysis } \\
\text { (Logrank } P \text { ) }\end{array}$ \\
\hline IPI00025311 & 584 & 61.7 & Breast carcinoma-amplified sequence 1 & bcas1 & 11.28 & $1.3 \mathrm{E}-06$ & $-3.2 \mathrm{E}-5$ \\
\hline IPI00017526 & 95 & 10.4 & Protein S100-P & s100p & 5.20 & $2.3 \mathrm{E}-08$ & $1.7 \mathrm{E}-6$ \\
\hline IPI00218831 & 218 & 25.7 & Glutathione S-transferase Mu 1 & gstm1 & 3.70 & 8.6E-07 & $-3.8 \mathrm{E}-11$ \\
\hline IPI00183695 & 97 & 11.2 & Protein S100-A10 & s100a10 & 3.15 & $1.0 \mathrm{E}-07$ & $2.3 \mathrm{E}-5$ \\
\hline IPI00922108 & 1002 & 111.1 & Integrin alpha-V & itgav & 2.88 & $7.8 \mathrm{E}-06$ & $2.0 \mathrm{E}-9$ \\
\hline IPI00021267 & 976 & 108.2 & Ephrin type-A receptor 2 & epha2 & 2.81 & $3.1 \mathrm{E}-05$ & $-2.0 \mathrm{E}-9$ \\
\hline IPI00027341 & 348 & 38.5 & Macrophage-capping protein & capg & 2.80 & $2.3 \mathrm{E}-07$ & $3.9 \mathrm{E}-5$ \\
\hline IPI00106687 & 222 & 25.7 & Latexin & Ixn & 2.69 & $1.3 \mathrm{E}-05$ & 0.2 \\
\hline IPI00013895 & 105 & 11.7 & Protein S100-A11 & s100a11 & 2.51 & $3.0 \mathrm{E}-05$ & $5.1 \mathrm{E}-10$ \\
\hline IPI00455315 & 339 & 38.6 & Annexin A2 & anxa2 & 2.41 & 2.7E-08 & 0.93 \\
\hline IPI00297910 & 323 & 35.7 & Tumor-associated calcium signal transducer 2 & tacstd2 & 2.19 & $1.1 \mathrm{E}-06$ & 0.53 \\
\hline IPI00903145 & 583 & 68.5 & Radixin & $\mathrm{rdx}$ & 2.17 & $2.4 \mathrm{E}-06$ & 0.25 \\
\hline IPI00219301 & 332 & 31.5 & Myristoylated alanine-rich C-kinase substrate & marcks & 2.14 & $6.9 \mathrm{E}-06$ & -0.17 \\
\hline IPI00853146 & 167 & 19.2 & Caveolin & cav & 2.08 & $1.0 \mathrm{E}-03$ & $-4.2 \mathrm{E}-8$ \\
\hline IPI00215995 & 1051 & 116.5 & Integrin alpha-3 & itga3 & 2.00 & $2.0 \mathrm{E}-04$ & $-3.9 \mathrm{E}-9$ \\
\hline IPI00010414 & 329 & 36.0 & PDZ and LIM domain protein 1 & pdlim1 & 1.94 & $1.8 \mathrm{E}-06$ & -0.009 \\
\hline IPI00795633 & 448 & 52.3 & Clusterin & clu & 1.88 & $1.5 \mathrm{E}-04$ & -0.02 \\
\hline IPI00010214 & 104 & 11.7 & Protein S100-A14 & s100a14 & 1.87 & $2.1 \mathrm{E}-04$ & 0.96 \\
\hline IPI00465431 & 250 & 26.1 & Galectin-3 & Igals3 & 1.79 & $2.5 \mathrm{E}-06$ & 0.28 \\
\hline IPI00219219 & 135 & 14.7 & Galectin-1 & lgals1 & 1.78 & $2.0 \mathrm{E}-04$ & 0.008 \\
\hline IPI00018364 & 183 & 20.5 & Ras-related protein Rap-2b & rap2b & 1.71 & $7.5 \mathrm{E}-05$ & $6.7 \mathrm{E}-6$ \\
\hline IPI00016485 & 394 & 42.7 & Protein phosphatase slingshot homolog 3 & $\operatorname{ssh} 3$ & 1.68 & $1.1 \mathrm{E}-03$ & $-2.4 \mathrm{E}-11$ \\
\hline IPI00217563 & 798 & 88.4 & Integrin beta-1 & itgb1 & 1.64 & $3.8 \mathrm{E}-08$ & $6.9 \mathrm{E}-12$ \\
\hline IPI00180240 & 44 & 5.1 & Thymosin beta-4-like protein 3 & tmsl3 & 1.63 & 3.7E-07 & $1.7 \mathrm{E}-5$ \\
\hline IPI00641181 & 195 & 19.5 & MARCKS-related protein & marcksl1 & 1.55 & 3.6E-06 & 0.011 \\
\hline IPI00759759 & 327 & 37.1 & $\begin{array}{l}\text { Epidermal growth factor receptor kinase } \\
\text { substrate } 8 \text {-like protein } 2\end{array}$ & eps812 & 1.53 & $2.4 \mathrm{E}-03$ & -0.13 \\
\hline IPI00021828 & 98 & 11.1 & Cystatin-B & cstb & 1.52 & 4.2E-04 & 4.7E-5 \\
\hline IPI00001871 & 340 & 36.5 & PRKC apoptosis WT1 regulator protein & pawr & 1.47 & $1.9 \mathrm{E}-04$ & 0.23 \\
\hline IPI00843975 & 586 & 69.4 & Ezrin & ezr & 1.41 & 4.0E-04 & $1.8 \mathrm{E}-5$ \\
\hline IPI00847442 & 92 & 10.1 & FK506 binding protein 12 & fkbp12 & 1.40 & $1.4 \mathrm{E}-05$ & 0.0011 \\
\hline IPI00022462 & 760 & 84.8 & Transferrin receptor protein 1 & tfre & 1.40 & $1.2 \mathrm{E}-05$ & 0.00049 \\
\hline IPI00005585 & 124 & 13.7 & Tax1-binding protein 3 & tax1bp3 & 1.39 & $5.5 \mathrm{E}-06$ & $6.7 \mathrm{E}-6$ \\
\hline IPI00016179 & 98 & 11.5 & Protein S100-A13 & s100a13 & 1.39 & 7.6E-09 & 0.15 \\
\hline IPI00005202 & 247 & 26.2 & $\begin{array}{l}\text { Membrane-associated progesterone receptor } \\
\text { component } 2\end{array}$ & pgrmc2 & 1.38 & $2.2 \mathrm{E}-04$ & $3.6 \mathrm{E}-5$ \\
\hline IPI00015148 & 184 & 20.8 & Ras-related protein Rap-1b & rap1b & 1.36 & $5.7 \mathrm{E}-06$ & $2.3 \mathrm{E}-5$ \\
\hline IPI00291175 & 1066 & 116.6 & Vinculin & $\mathrm{vcl}$ & 1.35 & $2.3 \mathrm{E}-05$ & -0.11 \\
\hline IPI00375426 & 323 & 36.2 & Cathepsin $\mathrm{H}$ & ctsh & 1.34 & 3.6E-04 & -0.44 \\
\hline IPI00011285 & 714 & 81.8 & Calpain-1 catalytic subunit & capn1 & 1.33 & $6.1 \mathrm{E}-06$ & -0.22 \\
\hline IPI00020599 & 417 & 48.1 & Calreticulin & calr & 1.31 & $3.3 \mathrm{E}-06$ & 0.67 \\
\hline IPI00009342 & 1657 & 189.1 & Ras GTPase-activating-like protein IQGAP1 & iqgap1 & 1.29 & $7.9 \mathrm{E}-07$ & $1.0 \mathrm{E}-4$ \\
\hline IPI00010080 & 527 & 58.0 & Serine/threonine-protein kinase OSR1 & oxsr1 & 1.28 & $5.0 \mathrm{E}-04$ & 0.49 \\
\hline IPI00478231 & 193 & 21.8 & Transforming protein RhoA & rhoa & 1.28 & $4.8 \mathrm{E}-07$ & 0.016 \\
\hline IPI00012011 & 166 & 18.5 & Cofilin-1 & $\mathrm{cfl} 1$ & 1.28 & $1.5 \mathrm{E}-05$ & $-7.9 \mathrm{E}-8$ \\
\hline IPI00025084 & 268 & 28.3 & Calpain small subunit 1 & capn2 & 1.26 & $1.4 \mathrm{E}-05$ & $-1.6 \mathrm{E}-12$ \\
\hline IPI00013808 & 911 & 104.8 & Alpha-actinin-4 & actn4 & 1.24 & $1.5 \mathrm{E}-04$ & 0.64 \\
\hline IPI00000513 & 821 & 90.9 & E-cadherin & cdh1 & 1.24 & $6.6 \mathrm{E}-05$ & $1.5 \mathrm{E}-7$ \\
\hline IPI00220739 & 195 & 21.7 & $\begin{array}{l}\text { Membrane-associated progesterone receptor } \\
\text { component } 1\end{array}$ & pgrmc1 & 1.23 & $1.1 \mathrm{E}-03$ & $5.7 \mathrm{E}-7$ \\
\hline IPI00028091 & 418 & 47.3 & Actin-related protein 3 & actr3 & 1.23 & 4.8E-04 & $2.4 \mathrm{E}-14$ \\
\hline
\end{tabular}


Table 1 Selected up-regulated proteins in tamoxifen resistant breast cancer cells (Continued)

\begin{tabular}{llllllll}
\hline IPI00217519 & 206 & 23.6 & Ras-related protein Ral-A & rala & 1.21 & $3.6 \mathrm{E}-03<1.0 \mathrm{E}-16$ \\
IPI00922213 & 1014 & 111.2 & fibronectin 1 & fn1 & 1.19 & $3.4 \mathrm{E}-02$ & 0.46 \\
IPI00220847 & 1745 & 194.3 & Integrin beta-4 & itgb4 & 1.19 & $6.3 \mathrm{E}-04$ & -0.12 \\
IPI00016786 & 191 & 21.2 & Cell division control protein 42 homolog & cdc42 & 1.15 & $5.2 \mathrm{E}-05$ & $-4.3 \mathrm{E}-10$ \\
\hline
\end{tabular}

relative protein quantities in the two cell lines, may not be biologically relevant to acquired tamoxifen resistance.

When the minimum fold change value was set at two times the standard deviation of all protein ratios in the control sample, the total number of significantly changed proteins was reduced to 629 with 364 up-regulated and 265 down-regulated (Additional file 2 Table S2). Listed in Tables 1 and 2 are proteins selected for either their large fold changes or perceived relevance to breast cancer progression and adaptation to anti-estrogen treatment. Multiple, functionally distinct proteins are seen dramatically altered in their expression in the resistant cell line. Importantly, ER regulated proteins such as cathepsin D and trefoil factor1 (TFF1/PS2) were downregulated, suggesting that suppression of ER signaling pathways is characteristic of tamoxifen resistance in vitro. Down-regulation of cathepsin D and TFF1/PS2 has also been reported in antihormone treated breast cancer cells [33].

Several of the up-regulated proteins are involved in the compensatory mechanisms for survival and proliferation in response to the anti-estrogen challenge. For example, up-regulation of TROP2 suggests increased survival signaling by activating ERK $1 / 2$ mediated cell cycle progression [34]. Overexpression of the antiapoptotic protein, CLU in the tamoxifen resistant cells suggests that it plays a role in counteracting the growth inhibition effects of tamoxifen.

Another group of differentially expressed proteins are associated with increased cancer cell motility and invasiveness, which include EphA2, BCAS1, S100 protein family members, Rho family members, Ral-A, Rab family members, Cdc42, MARCKS, Ezrin, Galectins 1 and 3 among others. These proteins are generally up-regulated and appear to regulate the cytoskeleton dynamics of the resistant cells leading to a more motile and aggressive phenotype.

To determine if the observed proteomic changes are due to acquired tamoxifen resistance or other changes including passaging the MCF-7 cells for 12 months, a three-way quantitative proteomic control experiment was performed in which an early passage \#13 (week 12), mid passage \#25 (week 27), and late passage \#50 (week 58) MCF-7-control cells are compared. A total of 635 proteins were compared for their relative abundances by the fold-change ratios with statistical assessment ( $P$-values) (Additional file 3 Table S3). These data confirm that there are no significant proteomic alterations within the MCF-7-control cells after a prolonged period of culture that are comparable to those occurring in the MCF-7-TamR cells. The relatively small fold changes in some protein expressions are not associated with the consistent, statistically significant changes occurring in the MCF-7-TamR resulting from development of resistance to tamoxifen. Overall, these data demonstrate that the progressive culturing of cells over a year in tamoxifen results in changes that are distinct from matched parental cells grown under normal culture medium conditions.

\section{Proteomic differential expressions are consistent with those at the transcriptional $2^{\text {nd }}$ el}

To investigate whether the changes observed in protein expression are a result of transcriptional regulation, we performed quantitative real-time PCR of 20 differentially expressed proteins. Because expression levels of mRNA do not always parallel those of the proteins due to additional regulatory processes, such as post-transcriptional modifications, we sought to first validate the proteomic findings at the transcriptional level. As shown in Figure 3, changes in mRNA expression are consistent with proteomic fold changes. For example, the most prominently up-regulated gene, S100P (180-fold), was also one of the most significantly overexpressed proteins (5.2-fold). EphA2, a receptor tyrosine kinase that was overexpressed by nearly 3 -fold in MCF-7-TamR, was up-regulated by 19-fold at the transcription level. Quantitative RT-PCR also confirmed the transcriptional down-regulation of several proteins whose concentrations were significantly decreased (for example, CA2, CTSD, starD10). Importantly, these results indicate that as a stable, tamoxifen resistant cell line, MCF-7TamR has incurred extensive alterations in the proteome, and that these changes are paralleled at the transcriptional level.

\section{Western blots confirm proteomics fold changes}

Recent advancement in proteomic techniques has made quantitative analysis of protein expression an ideal discovery tool with unprecedented reliability and breadth of scope. The multiple-channel labeling approach combined with high resolution mass spectrometry employed in this study provided an additional level of confidence and reproducibility to the proteomic results. However, when targets are narrowed down to individual functionally relevant 
Table 2 Selected down-regulated proteins in tamoxifen resistant breast cancer cells

\begin{tabular}{|c|c|c|c|c|c|c|c|}
\hline Accession & \#AAs & $\begin{array}{l}\mathrm{MW} \\
{[\mathrm{kDa}]}\end{array}$ & Description & $\begin{array}{l}\text { Gene } \\
\text { symbols }\end{array}$ & $\begin{array}{l}\text { Fold Change } \\
\text { TamR/Ctrl }\end{array}$ & $\begin{array}{l}\text { t-test } \\
\text { (p } \\
\text { values) }\end{array}$ & $\begin{array}{l}\text { Relapse free survival analysis } \\
\text { (Logrank P) }\end{array}$ \\
\hline IPI00218414 & 260 & 29.2 & Carbonic anhydrase 2 & $\mathrm{ca} 2$ & -2.70 & $1.3 \mathrm{E}-05$ & 0.79 \\
\hline IPI00032808 & 219 & 24.3 & Ras-related protein Rab-3D & rab3d & -2.36 & 4.5E-06 & $1.2 \mathrm{E}-4$ \\
\hline IPI00472076 & 175 & 19.4 & tumor protein D53 & $\operatorname{tpd} 5211$ & -2.03 & 7.5E-06 & 0.66 \\
\hline IPI00012866 & 480 & 55.7 & $\begin{array}{l}\text { RAC-alpha serine/threonine-protein } \\
\text { kinase }\end{array}$ & akt1 & -1.95 & 3.4E-06 & -0.028 \\
\hline IPI00647268 & 189 & 21.6 & Ras homolog gene family, member $C$ & rhoc & -1.86 & $6.4 \mathrm{E}-06$ & -0.019 \\
\hline IPI00025318 & 114 & 12.8 & $\begin{array}{l}\text { SH3 domain-binding glutamic acid- } \\
\text { rich-like protein }\end{array}$ & sh3bgrl & -1.75 & $2.4 \mathrm{E}-05$ & $3.8 \mathrm{E}-5$ \\
\hline IPI00550020 & 102 & 11.5 & Parathymosin & ptms & -1.74 & $5.2 \mathrm{E}-06$ & 0.095 \\
\hline IPI00186008 & 291 & 33.0 & PCTP-like protein & stard10 & -1.74 & 9.7E-04 & NA \\
\hline IPI00011564 & 198 & 21.6 & Syndecan-4 & sdc4 & -1.68 & $2.1 \mathrm{E}-04$ & NA \\
\hline IPI00019502 & 1960 & 226.4 & Myosin-9 & myh9 & -1.63 & $5.8 \mathrm{E}-06$ & -0.085 \\
\hline IPI00011696 & 845 & 98.3 & Proto-oncogene vav & vav1 & -1.58 & 4.8E-02 & $6.2 \mathrm{E}-11$ \\
\hline IPI00022283 & 84 & 9.1 & Trefoil factor 1 & tff1 & -1.54 & $1.5 \mathrm{E}-04$ & $1.5 \mathrm{E}-5$ \\
\hline IPI00550900 & 172 & 19.6 & Translationally-controlled tumor protein & tpt1 & -1.51 & $1.4 \mathrm{E}-06$ & $1.1 \mathrm{E}-10$ \\
\hline IPI00019345 & 184 & 21.0 & Ras-related protein Rap-1A & rap1a & -1.50 & $1.2 \mathrm{E}-05$ & $-9.5 \mathrm{E}-8$ \\
\hline IPI00479997 & 149 & 17.3 & Stathmin & stmn1 & -1.47 & $1.5 \mathrm{E}-05$ & $-2.9 \mathrm{E}-12$ \\
\hline IPI00011229 & 412 & 44.5 & Cathepsin D & ctsd & -1.45 & $5.9 \mathrm{E}-07$ & 0.56 \\
\hline IPI00216319 & 246 & 28.2 & 14-3-3 protein eta & ywhah & -1.45 & $5.5 \mathrm{E}-04$ & -0.066 \\
\hline IPI00217975 & 586 & 66.4 & Lamin-B1 & Imnb1 & -1.43 & $2.3 \mathrm{E}-05$ & 0.32 \\
\hline IPI00414676 & 724 & 83.2 & Heat shock protein HSP 90-beta & hsp90ab1 & -1.40 & $5.9 \mathrm{E}-07$ & $5.6 \mathrm{E}-7$ \\
\hline IPI00246975 & 225 & 26.5 & Glutathione S-transferase Mu 3 & gstm3 & -1.37 & $8.9 \mathrm{E}-07$ & 0.008 \\
\hline IPI00009607 & 183 & 20.7 & Ras-related protein Rap-2c & rap2c & -1.36 & $2.4 \mathrm{E}-03$ & $-3.1 \mathrm{E}-6$ \\
\hline IPI00020904 & 358 & 40.9 & Serine/threonine-protein kinase PRKX & prkx & -1.33 & $6.5 \mathrm{E}-03$ & 0.7 \\
\hline IPI00000041 & 196 & 22.1 & Rho-related GTP-binding protein RhoB & rhob & -1.33 & 2.0E-03 & 0.0032 \\
\hline IPI00003815 & 204 & 23.2 & Rho GDP-dissociation inhibitor 1 & arhgdia & -1.27 & $1.5 \mathrm{E}-03$ & 0.0042 \\
\hline IPI00955014 & 297 & 34.1 & cell division control protein 2 homolog & cdk1 & -1.26 & $6.1 \mathrm{E}-04$ & NA \\
\hline IPI00419235 & 229 & 26.9 & Glutathione S-transferase Mu 5 & gstm5 & -1.25 & $1.3 \mathrm{E}-04$ & $<1 \mathrm{E}-16$ \\
\hline IPI00941907 & 350 & 38.4 & $\begin{array}{l}\text { Serine-threonine kinase receptor- } \\
\text { associated protein }\end{array}$ & strap & -1.25 & 1.7E-05 & $-5.4 \mathrm{E}-9$ \\
\hline IPI00297261 & 435 & 49.9 & $\begin{array}{l}\text { Tyrosine-protein phosphatase non- } \\
\text { receptor type } 1\end{array}$ & ptpn1 & -1.25 & 4.3E-04 & $1.1 \mathrm{E}-11$ \\
\hline IPI00019812 & 499 & 56.8 & Serine/threonine-protein phosphatase 5 & ppp5c & -1.15 & 4.4E-04 & $7.4 \mathrm{E}-12$ \\
\hline
\end{tabular}

proteins, Western blotting offers a more specific and efficient method of validation as long as antibodies are available. To this end, we sought to confirm our proteomic findings of some of the most significant targets by Western blot. Semi-quantitative Western blot analysis of the MCF7-control and MCF-7-TamR cells was done for total protein levels of EphA2, S100P, TROP-2, StarD10 and MARCKS, all of which may be involved in the development of tamoxifen resistance. Results in Figure 4A, B show a statistically significant increase in the expression levels of EphA2 (approximately two-fold), S100P (approximately eight-fold), MARCKS (approximately three-fold), and TROP-2 (approximately three-fold) and a decrease in StarD10 (approximately two-fold) levels, confirming the differential expressions determined in both proteomic analysis and RT-PCR results.
Because proteomic analysis did not detect the presence and alterations of many receptors of key interests, including the tamoxifen target ER, we also performed Western blots to determine the status of ER $\alpha$ in the resistant cell line. Immunostaining clearly showed a marked decrease in total ER $\alpha$ protein level in the resistant cell line ( $>20$ fold), confirming that in the tamoxifen resistant MCF-7 cells obtained in our laboratory, ER $\alpha$ is significantly down-regulated but not lost (Figure 4A, B).

\section{ER regulated signaling pathways are suppressed but remain functional in MCF-7-TamR cells}

The observation of reduced expression of ER $\alpha$ in the resistant MCF-7 cells prompted us to ask whether ER regulated signaling is suppressed and, if so, whether ER remains functional. We first investigated the expression 


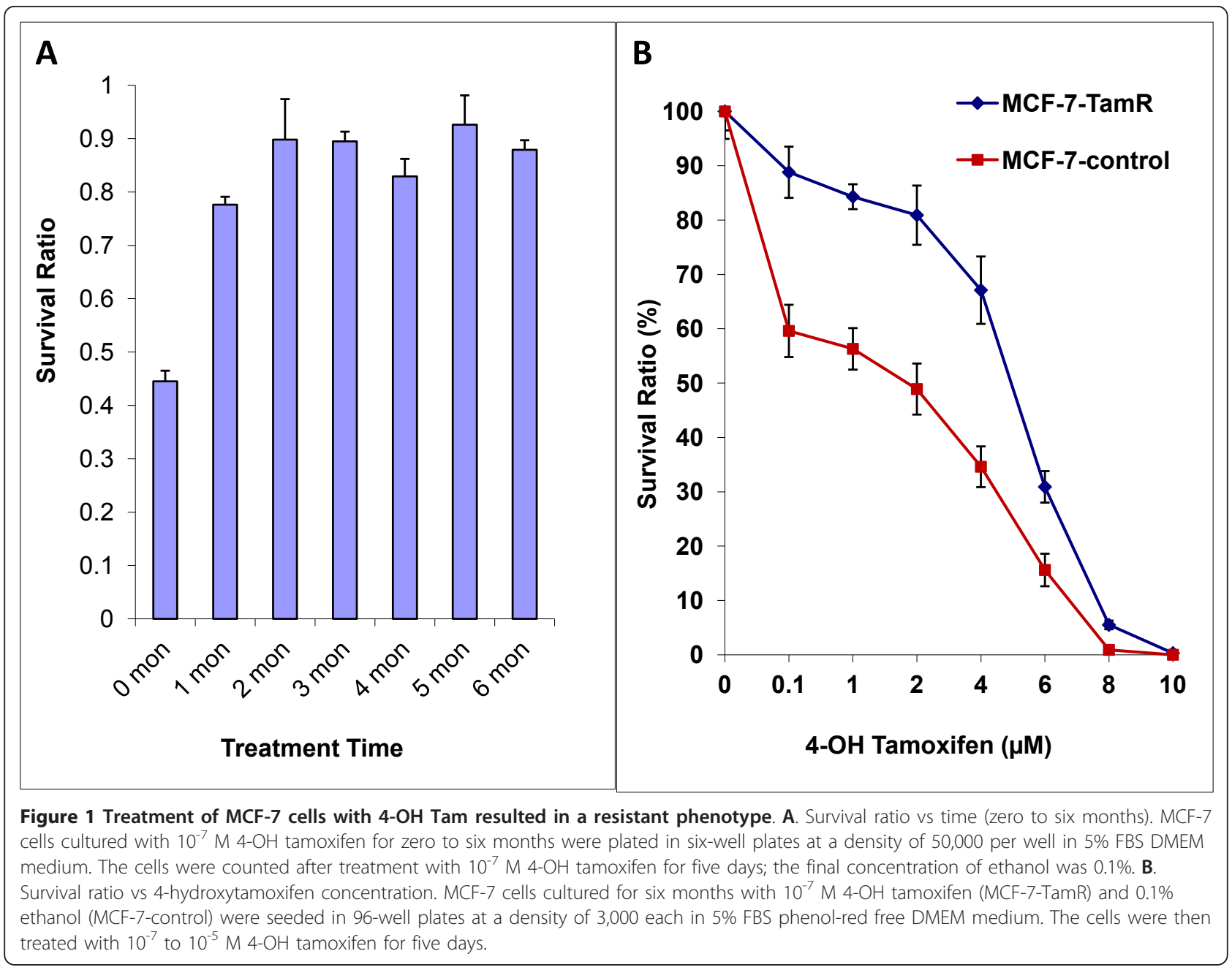

of two ER regulated genes, PgR and SDF-1 in MCF-7TamR and MCF-7-control cells (Figure 5A). Both PgR and SDF-1 were dramatically down-regulated in resistant cells when compared to DMSO treated control cells. For reference the ER gene expression was also determined by RT-PCR and was found to be greatly suppressed in the resistant cell line as its mRNA level was less than $10 \%$ that of the control. In MCF-7-control cells, treatment with $E_{2}$ induced a three-fold increase in PgR mRNA level (Figure 5A). However, in the resistant cells, while the PgR level was low, $E_{2}$ stimulation still caused a dramatic increase of PgR expression (Figure $5 B)$. This observation indicated that ER remained functional in tamoxifen-resistant MCF-7 cells, albeit to a much diminished extent. Similarly, the mRNA expression of SDF-1, an ER dependent gene was seen significantly down-regulated in MCF-7-TamR cells compared to the control cells (Figure 5A). Upon treatment with $E_{2}$, SDF-1 expression went up over two-fold, again suggesting that ER dependent signaling pathways remained functional after long term exposure to the anti-estrogen (Figure 5B).

\section{Pathway analysis reveals that actin cytoskeleton} regulation drives enhanced cell motility in TamR cells Gene ontology analysis using PANTHER [25] indicates that the significantly changed proteins constitute an over representation of "Cytoskeletal regulation by Rho GTPase pathway" $(P<0.0001)$ and "Integrin signaling pathway" $(P<0.0001)$ (Additional file 4 Figure S4). To understand the molecular signaling associated with these proteomic changes in the tamoxifen resistant cells we mapped our protein changes on a custom pathway derived from an original KEGG pathway framework (See Experimental section). Twenty-four proteins from our proteomic data were identified as involved in the regulation of cell motility, of which 21 showed statistically significant changes in expression levels (ACTB, ARP2/3, c-Src, CAPN1, CFL1, CRKL, DIAPH1, EphA2, EZR FN1, GNA13, IQGAP, ITGB, PFN2, RhoA, RDX, S100P, SSH3, TMSL3, VASP, 


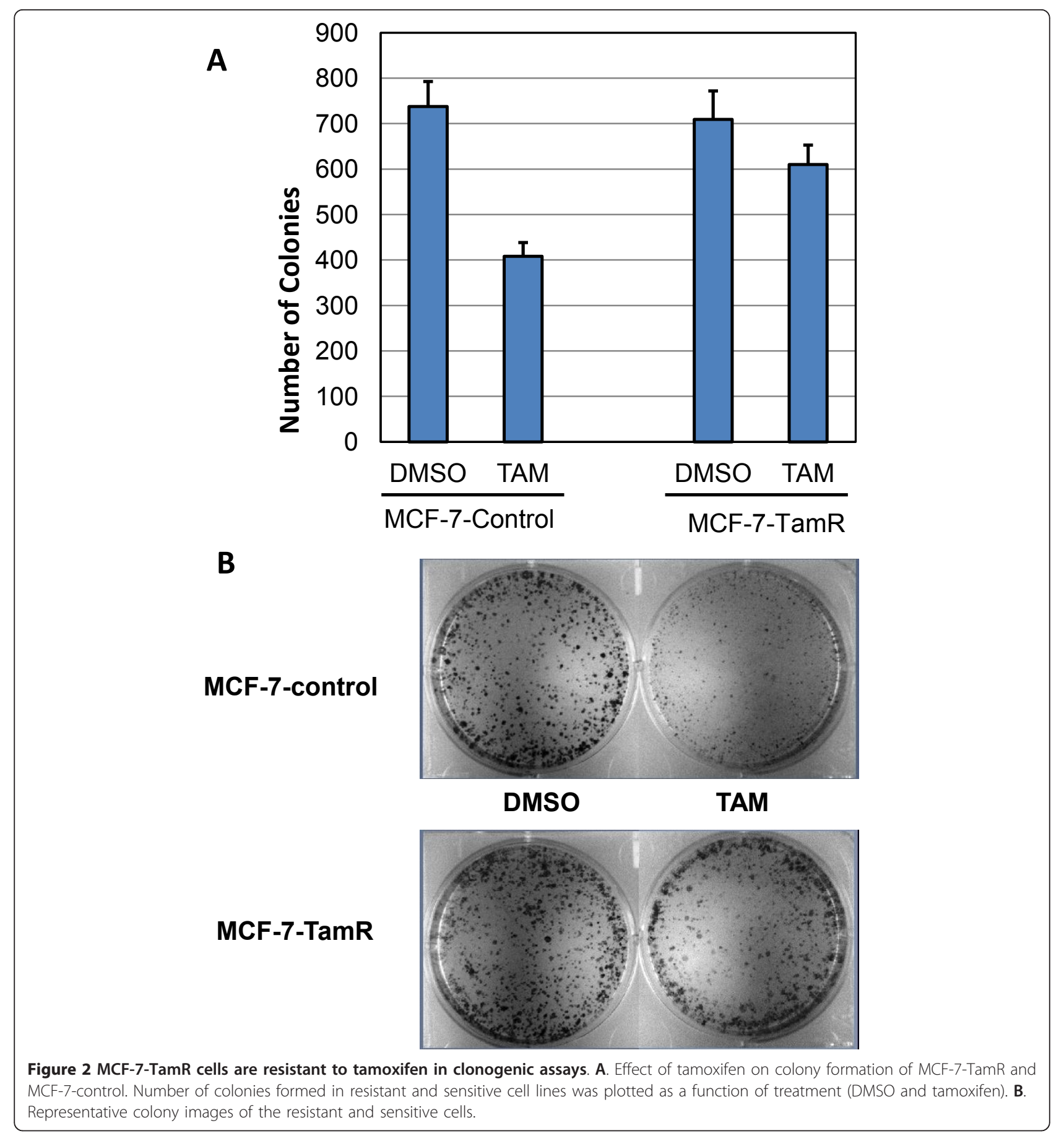

VCL). Figure 6 illustrates a reconstructed KEGG pathway map of actin cytoskeleton regulation. In one possible scenario, enhanced Rho-Rock signaling is enabled by increased expression of G-alpha 13 (GNA13) [35,36] and by EphA2-induced suppression of p190 RhoGap [37,38] (Figure 6, orange lines). In another signaling route depicted in the map, increased integrin-beta1 (ITGB) expression is implicated in the formation of focal adhesions with adaptor proteins talin, vinculin (VCL), actinin, filamin and other associated proteins such as vasodilator-stimulated phosphoprotein (VASP) [39]. This complex of integrins and proteins then binds to $\alpha$-actin and $\mathrm{f}$-actin through the Arp 2/3 complex. Up-regulation of several of these components indicate that the tamoxifen resistant cells are experiencing an increase of integrin mediated actin cytoskeleton regulation (Figure 6, green lines). 


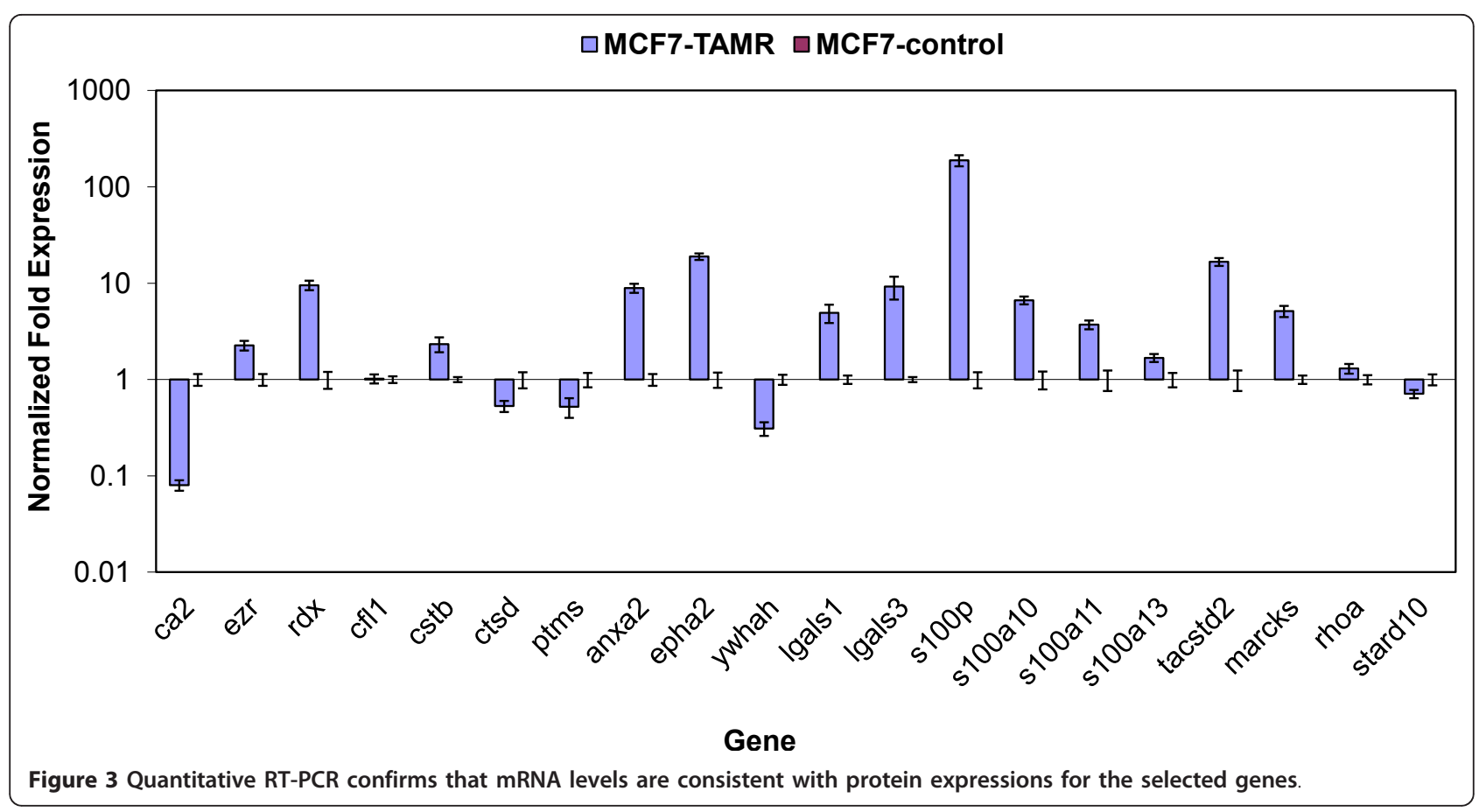

\section{MCF-7-TamR cells exhibit enhanced motility}

The KEGG pathway analysis based on the proteomic data indicates that up-regulation of cytoskeleton related pathways may facilitate migration of MCF-7-TamR cells. To confirm this, we carried out transwell migration assays. When MCF-7-control and MCF-7-TamR cells were seeded at a density of $2.5 \times 10^{4}$ in media free of serum and phenol red, the tamoxifen resistant cells were found to migrate faster than the tamoxifen sensitive control cells. As shown in Figure 7, MCF-7-TamR cell demonstrated increased basal migration by eightfold (100\% migration compared to $13 \%$ for MCF-7control cells). This result suggests that tamoxifen resistance is associated with enhanced cell motility, consistent with previous reports that antiestrogens promote breast cancer motility and invasion $[12,40,41]$.

\section{S100P plays an important role in acquired tamoxifen resistance and enhanced cell motility}

We next sought to investigate the role of S100P, a significantly up-regulated protein in MCF-7-TamR cells in conferring tamoxifen resistance and increased migration. As shown in Figure 8A, since the parental MCF-7 cell line expresses negligible level of S100P compared to the resistant cells, we decided to overexpress it in MCF-7 cells by a lentiviral transduction of the S100P gene. The resulting MCF-7-S100P cells exhibited a dramatic increase in S100P expression (Figure 8A). Subsequent survival assays demonstrated that stable overexpression of S100P in MCF-7 cells enhanced their resistance to tamoxifen when compared to the control. As illustrated in Figure $8 \mathrm{~B}$, after treatment with 4-OH Tam for five days at $10^{-7}$ $\mathrm{M}$, the survival ratio of MCF-7-S100P cells was significantly higher than the control MCF-7 cells (80\% vs $60 \%$, $P<0.001)$. The effect of S100P up-regulation on MCF-7 cell motility was also investigated by transwell migration assays. In Figure 8C, MCF-7 cells stably overexpressing S100P demonstrated over 60\% $(P<0.05)$ increase in migratory capacity compared to the MCF-7-control cells.

\section{Survival analysis reveals relevance of many altered proteins to breast cancer prognosis}

To assess the relevance of the altered expression levels of various proteins on the clinical outcome in breast cancer patients, we performed survival analysis of up- and down-regulated proteins selected in Tables 1 and 2 using an online survival analysis tool. The online database contains the expression of 22,277 genes and survival information of 1,809 patients [31]. As shown in the last columns of Tables 1 and 2, alterations in the expression level of many proteins in tamoxifen resistant cells were found to positively correlate with decreased survival. For example, the up-regulation of S100P, S100A10, S100A11, integrin alpha-V (itgav), macrophage-capping protein (capg), ezrin and RhoA appear to be predictive of poor survival (Table 1). On the other hand, down-regulation of a number of proteins such as proto-oncogene vav (vav1), trefoil factor 1 (tff1/PS2), translationally-controlled tumor protein (tpt1), glutathione S-transferase Mu 5 (gstm5), tyrosine-protein phosphatase non-receptor 


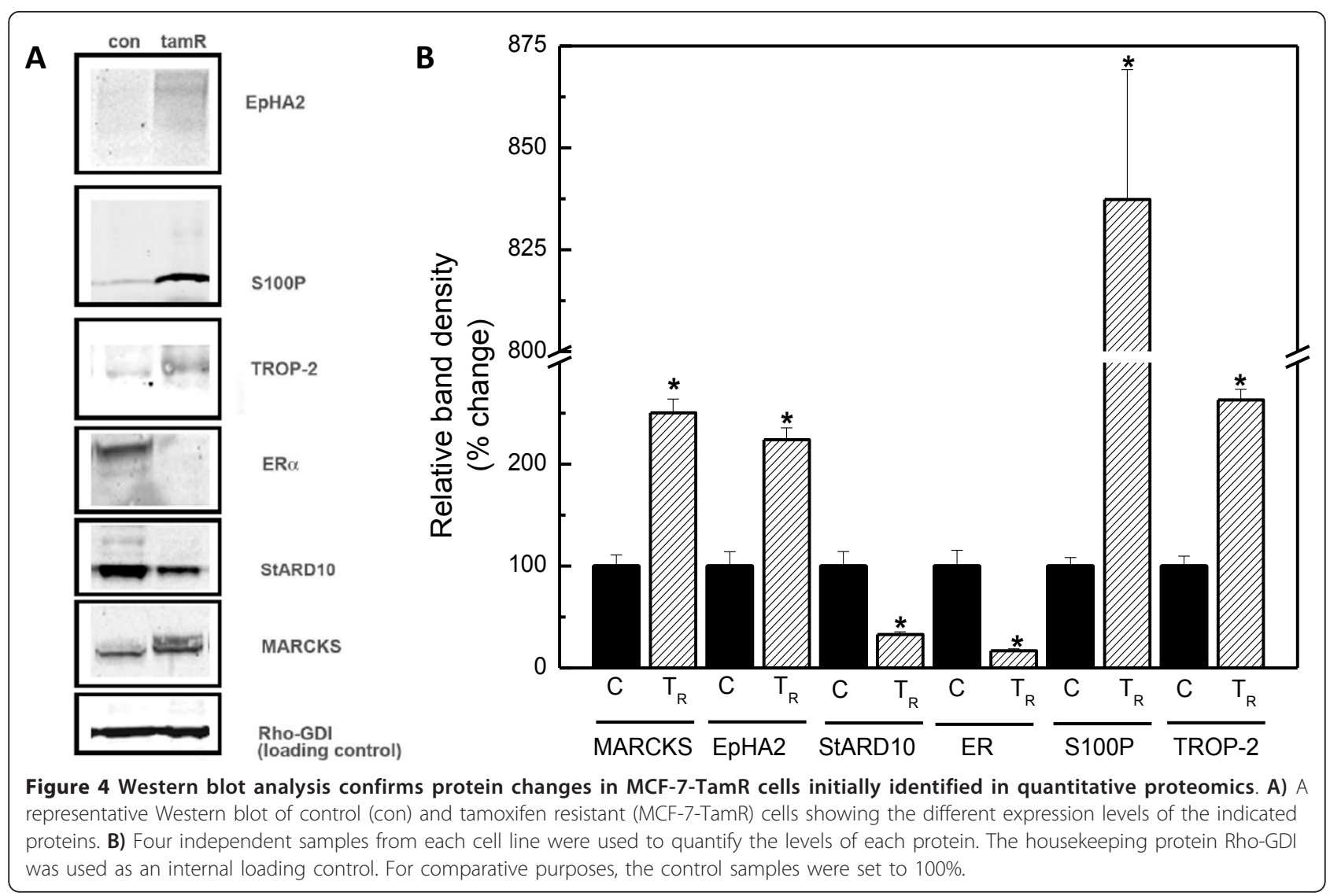

type 1 (ptpn1), and heat shock protein HSP 90-beta (hsp90ab1), are also significantly correlated to poor prognosis and decreased survival. However, tamoxifen resistance appears to induce expression changes of numerous proteins that are associated with improved survival in clinical results. For instance, the overexpression of breast carcinoma-amplified sequence 1 (bcas1), glutathione $S$ transferase $\mathrm{Mu} 1$ (gstm1), ephrin A2 receptor (epha2), caveolin (cav), calpain small subunit 1 (capn2) and the down-regulation of stathmin (stmn1), serine-threonine kinase receptor-associated protein (strap), Ras-related protein Rap-1A (rap1a) all point to a better prognosis as indicated by the Kaplan-Meier survival curves (see negative long-rank $P$-values in the last columns of Tables 1 and 2).

Figure 9A-D represents the Kaplan-Meier survival plots for S100P gene using two different survival options (Figure 9A, C) and two patient cohorts (Figure 9B, D). Up-regulation of S100P is correlated to reduced survival over a period of 20 years for both relapse free survival $(P=1.7 \mathrm{e}-6)$ and distant metastasis free survival $(P=$ 0.029 ). For systematically untreated patients, overexpression of S100P gene is again predictive of lower relapse free survival rate $(P=0.017)$ but not statistically significant for prognosis of distant metastasis free survival
$(P=0.18)$. Shown in Figure 9E, $\mathrm{F}$ are Kaplan-Meier survival curves where breast cancer subtyping is used based on ER status. For the ER (+) subgroup, overexpression of S100P is significantly associated with decreased survival (Figure 9E, $P=0.00037)$. However, this correlation is lost with ER(-) breast cancer patients (Figure 9F, P = 0.95), suggesting that S100P is not a useful predictor in hormone independent breast cancer subtypes. In addition, we found that the prognostic value of S100P in the available data set for ER+ endocrine treated patients (Figure 9G, H) was not significant.

\section{Discussion}

We have established a tamoxifen-resistant breast cancer cell line obtained under an FBS-containing medium condition to minimize adaptive cellular changes in response to LTED. Indeed, earlier studies have shown that LTED leads to enhanced expression of the estrogen receptor [42] or EGFR [14], which are not usually observed in tamoxifen resistant cell lines cultured in normal FBS medium $[13,15]$. In the MCF-7-TamR cell line obtained in this study after six months of 4-OH tamoxifen treatment, the estrogen receptor was significantly down-regulated but retained viable function (Figure 5). Current understanding of endocrine resistance depicts a progressive, stepwise 

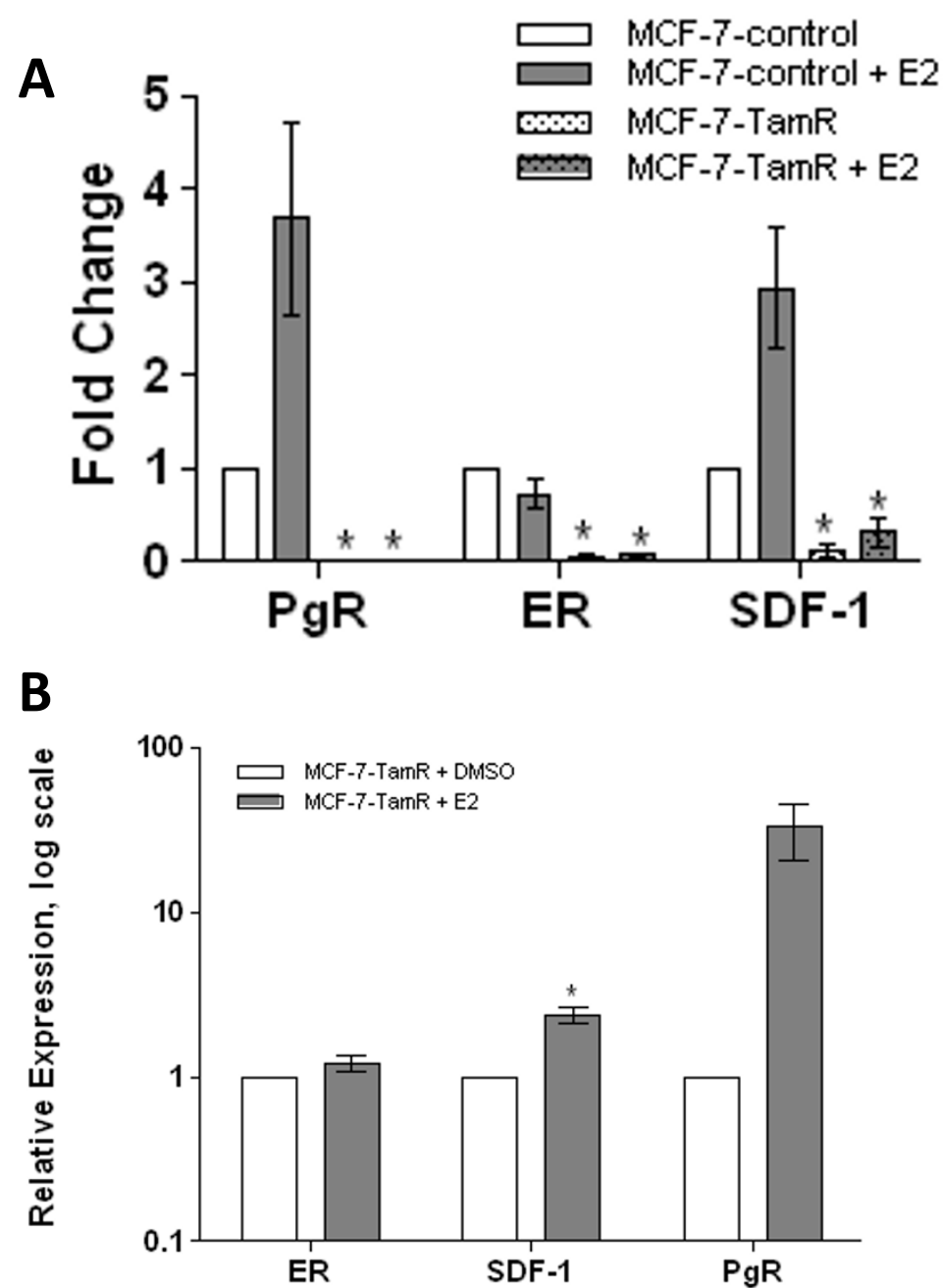

Figure 5 MCF-7-TamR cells exhibit significantly down-regulated ER mediated signaling pathways. A) MCF-7-Control and MCF-7-TamR cells were grown in 5\% phenol free DMEM for 48 hours prior to 24 hours treatment with $1 \mathrm{nM} 17 \beta$-estradiol ( $E_{2}$ ) or vehicle control (DMSO). Q PCR was performed for ER regulated genes ER, PgR, and SDF-1. Normalization was to MCF-7-control cells treated with vehicle; $\mathbf{B}) E_{2}$ induced ER regulated gene expression for tamoxifen resistant cells (normalization to MCF-7-TAMR treated with DMSO). GPCR was performed for genes ER, SDF-1, and PgR. Results reflect average fold change in cycle number for mRNA levels $+/$-. Cycle number was normalized to $\beta$-actin. * Significantly different from DMSO control, $P<0.05$.

process in response to anti-estrogen challenge where breast cancer cells evolve from an estrogen-dependent phenotype to a non-responsive one and eventually to a stage of estrogen independence. Our results indicate the tamoxifen resistant cells appear to be at a stage of minimized estrogen responsiveness without complete loss of ER. Previous studies of tamoxifen resistance using in vitro models suggest translocation of ER from nucleus to membrane, facilitating crosstalk with growth factor receptors and enhancing the non-genomic signaling of the ER. In these reports, the total ER levels remain largely unchanged $[13,15,42]$. On the other hand, complete loss of ER expression has occurred when MCF-7 cells became resistant to the pure antiestrogen, fulvestrant [43-45].
This in vitro behavior is also consistent with clinical observations that tamoxifen resistant tumors may still respond to fulvestrant [46,47] and that only 15 to $30 \%$ of patients present with complete loss of ER at time of relapse $[11,48,49]$. The down-regulation of ER mediated signaling pathways in our MCF-7-TamR cells is corroborated by proteomic evidence that showed suppressed expression levels of cathepsin D and TFF1/PS2 and was confirmed by Western blot analysis showing diminished ER protein expression. PgR, an ER dependent gene, was also found significantly down-regulated ( $>1,000$-fold, Figure $5 \mathrm{~A}$ ) by RT-PCR analysis. On the other hand, $E_{2}$ stimulation did induce a 50-fold increase in PgR expression from its greatly suppressed basal level (Figure 5B) in the resistant cells. 


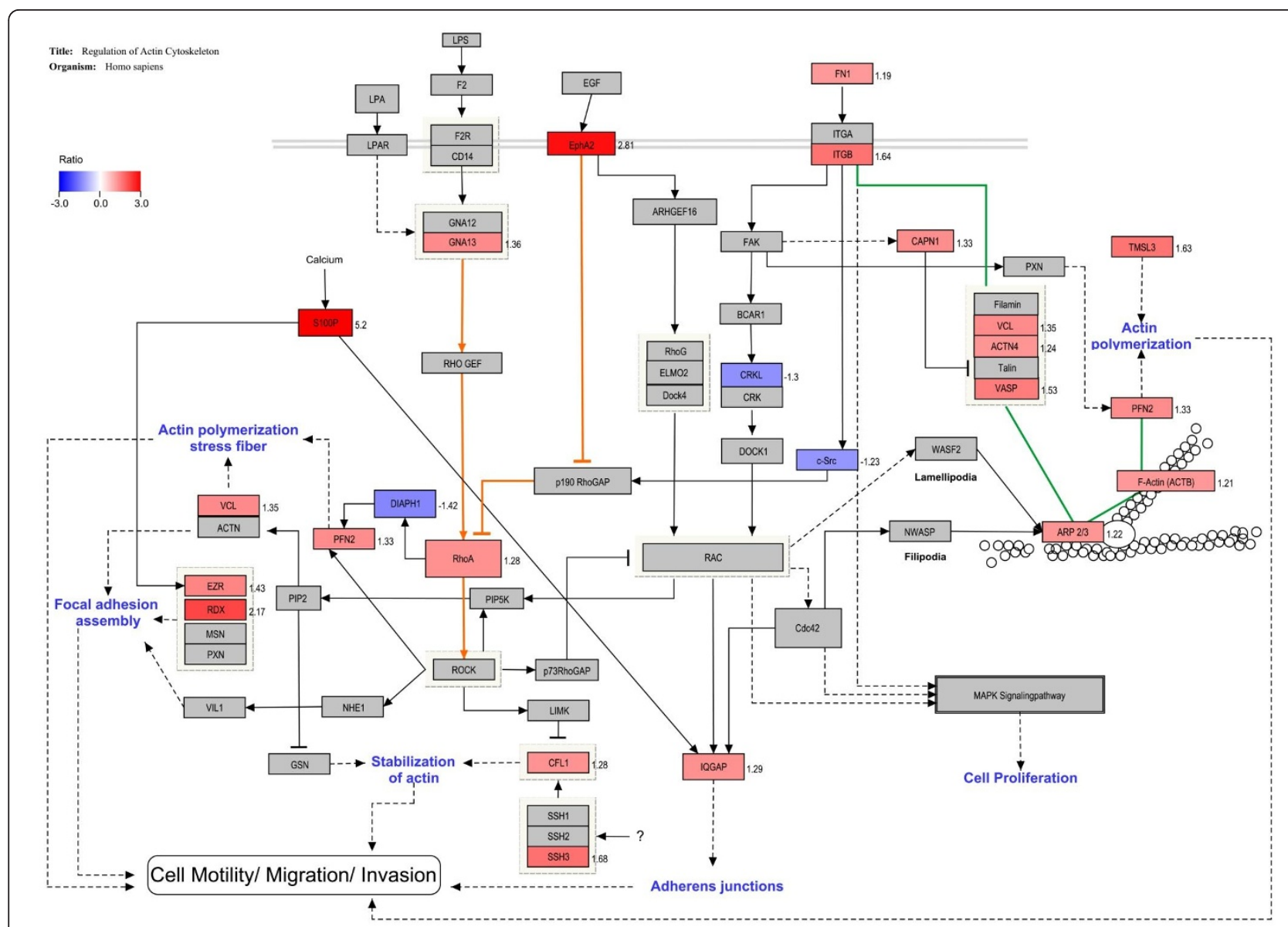

Figure 6 Regulation of actin cytoskeleton in the tamoxifen resistant cell line, MCF-7-TamR. The pathway illustrates changes to proteins expression, TamR cell line vs. control, involved in regulating the actin cytoskeleton. All red proteins are significantly up-regulated and all blue proteins are significantly down-regulated. The ratio value for each significantly regulated protein is indicated to the right. Solid lines with no arrow indicate physical interaction. Solid lines with an arrow or bar at the end indicate direct activation or inhibition, respectively. Dotted lines indicate indirect or unknown method of interaction. The orange lines highlight the Rho activation pathways and the green lines highlight integrin mediated focal adhesions.

In ER positive breast cancer cells, estrogen signaling is the main mediator of proliferation and tumor progression. Adaptation to tamoxifen challenge which blocks ER signaling must involve activation of alternative survival signaling to sustain growth and circumvent the apoptotic effect of tamoxifen. As demonstrated in numerous in vitro and in vivo studies on the mechanisms of tamoxifen resistance, tumor cells recruit a remarkably wide variety of signaling pathways to achieve the resistant outcome [50,51], including cross talk with EGFR and Her2 [52,53], and enhanced nongenomic signaling accompanied by translocation of ER $[54,55]$. Our study identified several proteins that are known to promote tumorigenesis and progression but their roles in tamoxifen resistance have not been explored. In particular, the up-regulation of S100P revealed a previously unknown link between tamoxifen resistance and the small calcium binding protein. S100P is a ligand for the receptor for advanced glycation end product (RAGE). Binding of the $\mathrm{Ca}^{2+}$ activated S100P homodimer to RAGE has been shown to promote cancer cell proliferation via the ERK1/2 and $\mathrm{NF} \kappa \mathrm{B}$ signaling pathways [56-58]. S100P was found to co-immunoprecipitate with RAGE and its action on cell survival and proliferation could be blocked by RAGE inhibitors [56].

The forced overexpression of S100P in the tamoxifen sensitive MCF-7 cell line increased its resistance to tamoxifen significantly (Figure 8B), confirming the role of S100P in acquired tamoxifen resistance. Our results suggest that, as the ER-regulated proliferation pathway was severely suppressed after prolonged exposure to tamoxifen, the S100P-RAGE signaling via activation of ERK1/2 and possibly NF- $\kappa \mathrm{B}$ is increased as a compensatory mechanism of cell proliferation and survival. 


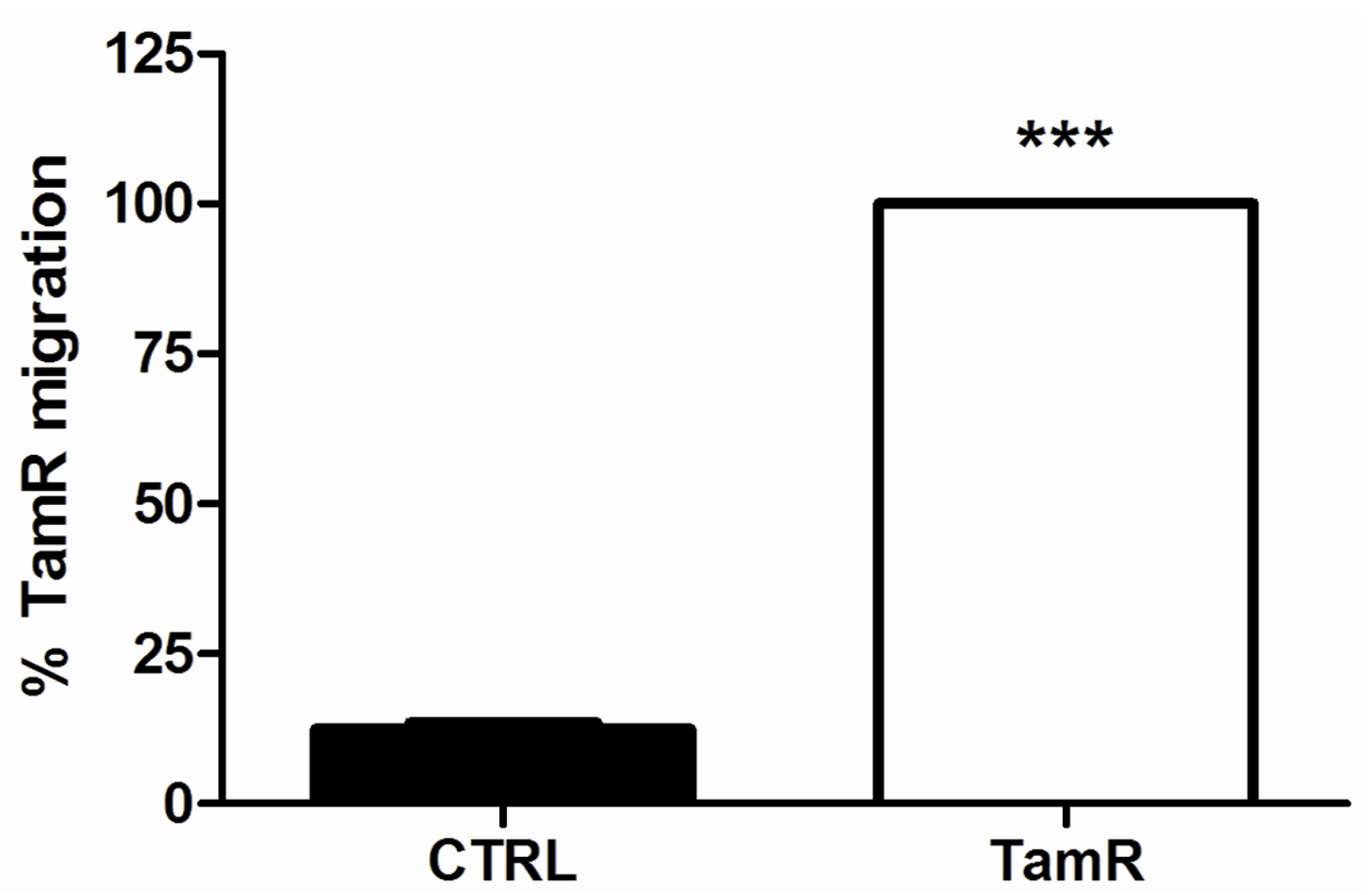

Figure 7 Acquired resistance to tamoxifen in MCF-7 cells leads to enhanced migration capacity. $2.5 \times 10^{4}$ MCF-7 or MCF-7-TamR cells were seeded on the upper chamber of a transwell system where the lower wells contained media with 5\% serum. After $24 \mathrm{~h}$, cells were fixed and stained with crystal violet and the number of migrated cells counted. Bars represent the percent of migrated MCF-TamR cells per $100 \times$ field of view \pm SEM. ${ }^{* * *}, P<0.001$

In addition, the up-regulation of the anti-apoptotic protein CLU can be viewed as another possible survival pathway contributing to tamoxifen resistance. Previous reports have implicated CLU up-regulation as a general defense mechanism of cancer cells toward cytostatic drugs [59-61]. Under cell stress, such as treatment with trastuzamab in breast cancer cells, or following androgen ablation in prostate cancer cells, significant increase in CLU expression was associated with activation of alternative signaling $[62,63]$.

Another significantly up-regulated protein, EphA2, may contribute to the survival of tamoxifen resistant cells. The EphA2 expression level in breast cancer cells has been found inversely related to ER expression $[64,65]$. This is consistent with our RT-PCR and Western blot results where ER was significantly down-regulated (Figures 4 and 5). EphA2-transfected cells demonstrated increased growth in vitro and form larger and more aggressive tumors in vivo [66]. Moreover, EphA2 overexpression decreased the ability of tamoxifen to inhibit breast cancer cell growth and tumorigenesis $[67,68]$. The finding in this study that EphA2 was overexpressed in a tamoxifen resistant cell line confirms the involvement of the receptor tyrosine kinase in the development of tamoxifen resistance in breast cancer.

As the cells adapt to the inhibitory effects of tamoxifen, the acquired resistance appears to transform the breast cancer cells into a more aggressive phenotype with increased motility. Indeed, many of the overexpressed proteins thought to regulate growth and proliferation in our TamR cells have also been implicated in promoting cancer cell migration and invasion. Gene Ontology and KEGG pathway analyses collectively using proteomic data suggest that regulation of actin cytoskeleton may be responsible for driving the motility of TamR cells. The novel role of S100P in the regulation of cytoskeleton dynamics was highlighted in the pathway map (Figure 6) in which S100P was involved in the interactions with ezrin [69], a membrane/F-actin cross-linking protein implicated in tumor metastasis [70-73], and with the scaffolding protein IQGAP1 [74], known to promote cell motility and invasion [75]. To confirm the involvement of S100P in regulation of tamoxifen induced cell motility, we conducted functional studies of S100P by overexpressing the protein in the parental MCF-7 cells and observed increased motility in MCF-7-S100P cells as a result 


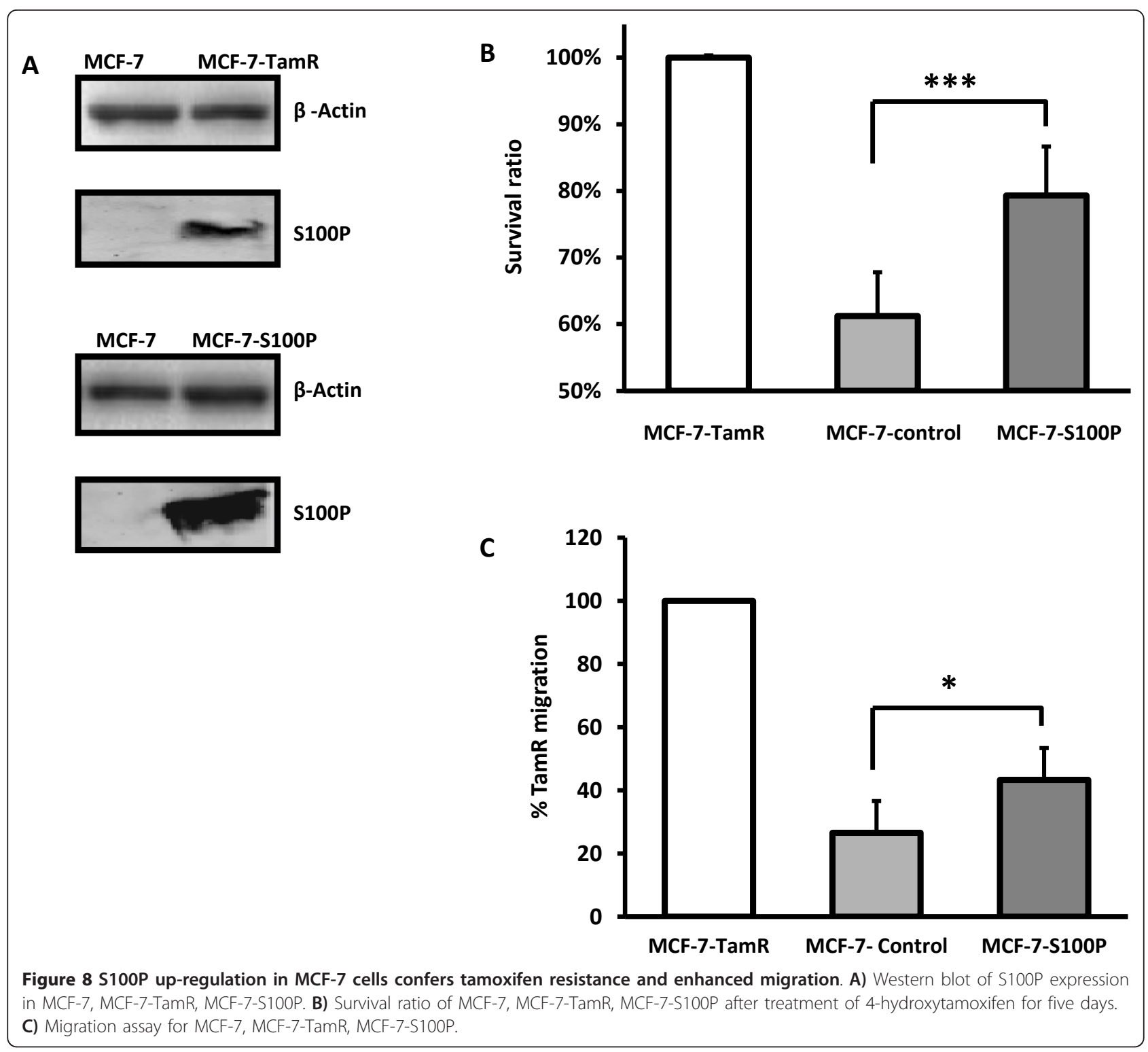

(Figure 8C). Moreover, our proteomic finding that both ezrin and IQGAP1 were up-regulated in the tamoxifen resistant cells (1.43- and 1.29-fold, respectively) provided additional evidence for the involvement of S100P in motility enhancement and suggests that the mechanism of action may involve the ezrin and IQGAP1 pathways.

Finally, overexpression of S100P and its role in mediating tamoxifen resistance and cell motility also bear clinical relevance. Using a GEO gene expression database from 1,809 breast cancer patients, the KaplanMeier survival plots demonstrate the prognostic relevance of S100P overexpression on patient survival. Overexpression of S100P is predictive of lower relapse free survival $(P=1.76 \mathrm{e}-6)$ and significantly correlated with decreased distant metastasis free survival $(P=$ 0.029). Furthermore, truly prognostic patient group, that is, systematically untreated breast cancer patients with higher levels of S100P tend to have shorter relapse free period $(P=0.017)$. Finally, S100P up-regulation appears to be significantly associated with reduced survival in $\mathrm{ER}(+)$ but not in $\mathrm{ER}(-)$ breast cancer patients.

\section{Conclusion}

Using a quantitative proteomic approach we have identified and verified key adaptive protein changes that are involved in the development of tamoxifen resistance. Long term treatment with 4-hydroxytamoxifen significantly suppressed ER-regulated signaling pathways in MCF-7 breast cancer cells. This was demonstrated in the marked downregulation of ER dependent genes, including PgR, PS2, and SDF-1. In response, alternative survival signaling was activated that appeared to involve the up-regulation of 

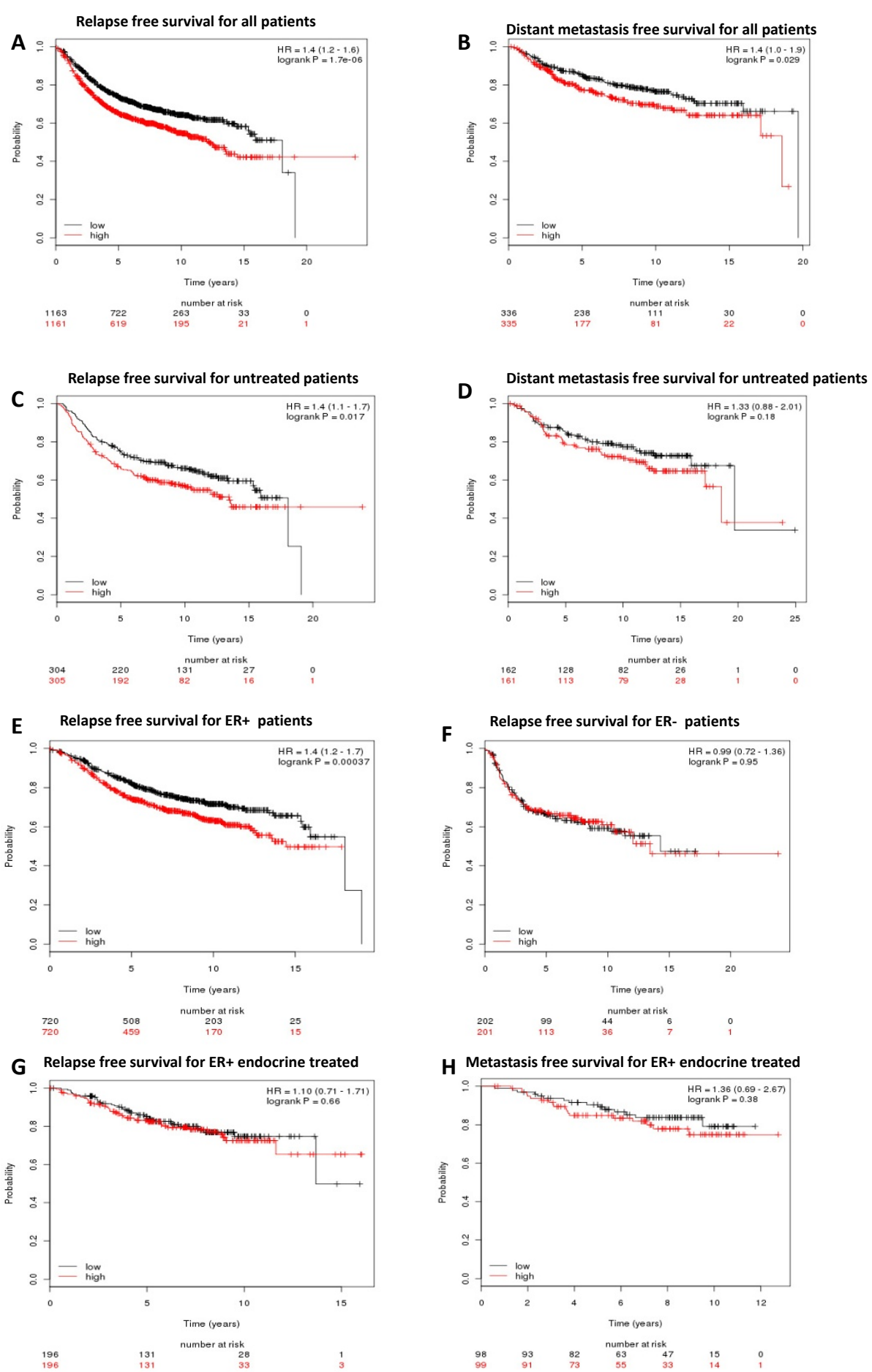

Figure 9 Kaplan-Meier survival plots demonstrate the prognostic relevance of S100P overexpression on patient survival. A) Overexpression of S100P is predictive of lower relapse free survival $(P=1.76 \mathrm{e}-6)$ for all patients; B) overexpression of S100P is correlated with decreased distant metastasis free survival $(P=0.029) ; \mathbf{C})$ Untreated breast cancer patients had lower relapse free survival if their tumors overexpressed S100P ( $P=0.017$ ); D) Weak correlation between the metastasis free survival and overexpression of S100P $(P=0.18)$; E) Higher level of S100P expression is predictive of poor relapse free survival for ER positive breast cancer patients $(P=0.00037)$; F) S100 overexpression is not associated with survival of ER negative breast cancer patients; G) S100 overexpression is not statistically significant for prognosis of ER positive endocrine treated patients; H) Overexpression of S100P is not predictive of metastasis-free survival of ER positive endocrine treated patients. 
multiple proteins. This was reflected in the global proteomic changes that included the increased expression of TROP2, CLU, MARCKS, and S100 family proteins. In particular, we identified S100P, an EF-hand calcium binding protein previously implicated in breast and other solid tumors, as a significant player in conferring tamoxifen resistance and cell motility. Overexpression of S100P in the hormone sensitive parental MCF-7 cells significantly increased resistance to tamoxifen. The mechanism of S100P action may involve its interaction with the receptor RAGE, leading to sustained survival and proliferation.

Proteomic analysis of MCF-7-TamR cells also revealed a critical phenotypic transformation of the cells towards an increased migratory capacity, consistent with most clinical outcomes where tumor invasion and metastasis follow the acquired hormone resistance in patients. The enhanced cell motility in the tamoxifen resistant cells appeared to be driven by the cytoskeletal dynamics where S100P played an important role. This was supported by the observation that overexpressing S100P in MCF-7 cells significantly increased cell migration. Additional evidence comes from proteomic data where up-regulation of multiple proteins in a coordinated signaling network may regulate the actin cytoskeleton dynamics as depicted in our proposed pathway model. Specifically, we observed the up-regulation of EphA2, RhoA, ITGB1, vinculin, ezrin, and radixin, which are key proteins contributing to the increased cell motility in a tamoxifen resistant phenotype by promoting actin fiber polymerization, filopodia formation, and cell contractability.

\section{Additional material}

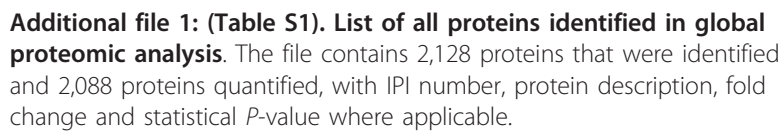

Additional file 2: (Table S2). List of significantly altered proteins from proteomic anlaysis. This file contains 629 significantly changed proteins as defined in the Results section where the significant fold change of proteins was defined as greater than two times standard deviation and $P<0.05$

Additional file 3: (Table S3). List of proteins identified and quantified in three MCF-7-control cell samples obtained at different passages. This file contains a total of 635 proteins with relative abundances by the fold-change ratios with statistical assessment ( $P$ values).

Additional file 4: (Figure S4). Gene ontology analysis of significantly altered proteins reveals overrepresentation of Integrin Signaling Pathway. This file contains the over or under representation of pathways determined using the web based program PANTHER http://www. pantherdb.org and the significantly up- and down-regulated proteins.

\section{Abbreviations}

actb: beta actin; anxa2: annexin 2; ca2: carbonic anhydrase 2; cfl1: cofilin; CID: collision-induced dissociation; CLU: clusterin; cstb: cystatin B; ctsd: cathepsin D; DCC: dextran coated charcoal-stripped; DMEM: Dulbecco's modified Eagle's medium; DMSO: dimethyl sulfoxide; EGFR: epidermal growth factor receptor; epha2: ephrin type-A receptor 2; ER: estrogen receptor; ezr: ezrin; HBSS: Hank's Buffered Salt Solution; HCD: high energy collision dissociation; Igals1: galectin-1; Igals3: galectin-3; ITGB: integrin-beta1; LTED: long term estrogen deprivation; marcks: myristoylated alanine-rich protein kinase C substrate; PgR: progesterone receptor; PMSF: phenylmethylsulfonyl fluoride; ptms: parathymosin; RAGE: receptor for advanced glycation end product; rdx: radixin; rhoa: Ras homolog gene family: member A; RFS: relapse free survival; Rho-GDI: Rho GDP-dissociation inhibitor; RT-PCR: reverse transcription polymerase chain reaction; s100a10: S100 protein A10; s100a11: S100 protein A11; s100a13: S100 protein A13; s100p: S100 protein P; SCX: strong cation exchange chromatography; SDF-1: stromal cell-derived factor-1; SPE: solid-phase extraction; stard10: StAR-related lipid transfer domain containing 10; Tam: tamoxifen; TCEP: tris(2-

carboxyethyl)phosphine; TEAB: triethyl ammonium bicarbonate; TMT: tandem mass tag; ywhah: tacstd2 (trop-2): tumor-associated calium signal transducer 2; VASP: vasodilator-stimulated phosphoprotein; VCL: vinculin.

\section{Acknowledgements}

This study was supported by a cooperative agreement with the U.S. Department of Agriculture Grant 58-6435-7-019; Department of Defense Grant W81XWH-04-1-0557; the Louisiana Cancer Research Consortium (LCRC); Office of Naval Research Grant N00014-99-1-0763, National Center for Research Resources RCMI program through Grant 5G12RR026260-02, and $\mathrm{NIH}$ grant CA125806 (MEB).

\section{Author details}

'Department of Chemistry, Xavier University of Louisiana, 1 Drexel Drive, New Orleans, LA 70125, USA. ${ }^{2}$ Blood Research Laboratory, Chengdu Blood Center, Chengdu, Sichuan 610041, China. ${ }^{3}$ RCMI Cancer Research Program, Xavier University of Louisiana, 1 Drexel Drive, New Orleans, LA 70125, USA. ${ }^{4}$ Department of Medicine, Tulane University School of Medicine, 1415 Tulane Ave., New Orleans, LA 70112, USA. ${ }^{5}$ Department of Pharmacology, Tulane University School of Medicine, 1415 Tulane Ave., New Orleans, LA 70112, USA.

\section{Authors' contributions}

CZ cultured cell lines, performed survival assays and proteomic sample preparation, RT-PCR, interpreted data and drafted the manuscript. QZ performed lentiviral transduction and subsequent functional studies of cell survival and migration, and contributed to drafting the revised manuscript. LR performed migration assays. IT performed bioinformatics analysis, while MRB performed Western blotting. QZ carried out HPLC-MS/MS based protein identification and database search. EM performed RT-PCR and SE performed colony assays. BMC and MEB participated in experimental design and interpretation, and critically revised the manuscript. GW designed the study, and drafted and critically revised the manuscript. All authors have read and approved the final manuscript.

\section{Competing interests}

The authors declare that they have no competing interests.

Received: 7 November 2011 Revised: 14 February 2012

Accepted: 14 March 2012 Published: 14 March 2012

\section{References}

1. Hutcheson IR, Knowlden JM, Madden TA, Barrow D, Gee JM, Wakeling AE, Nicholson RI: Oestrogen receptor-mediated modulation of the EGFR/ MAPK pathway in tamoxifen-resistant MCF-7 cells. Breast Cancer Res Treat 2003, 81:81-93.

2. Kurokawa $H$, Lenferink $A E$, Simpson JF, Pisacane Pl, Sliwkowski MX, Arteaga CL: Inhibition of HER2/neu (erbB-2) and mitogen-activated protein kinases enhances tamoxifen action against HER2overexpressing, tamoxifen-resistant breast cancer cells. Cancer Res 2000, 60:5887-5894.

3. Tokunaga E, Kimura Y, Mashino K, Oki E, Kataoka A, Ohno S, Morita M, Kakeji Y, Baba H, Maehara Y: Activation of PI3K/Akt signaling and hormone resistance in breast cancer. Breast Cancer 2006, 13:137-144.

4. Jeng MH, Yue W, Eischeid A, Wang JP, Santen RJ: Role of MAP kinase in the enhanced cell proliferation of long term estrogen deprived human breast cancer cells. Breast Cancer Res Treat 2000, 62:167-175. 
5. Schiff R, Massarweh SA, Shou J, Bharwani L, Mohsin SK, Osborne CK: Crosstalk between estrogen receptor and growth factor pathways as a molecular target for overcoming endocrine resistance. Clin Cancer Res 2004, 10:331S-336S.

6. Leary AF, Sirohi B, Johnston SR: Clinical trials update: endocrine and biological therapy combinations in the treatment of breast cancer. Breast Cancer Res 2007, 9:112.

7. Leary AF, Drury S, Detre S, Pancholi S, Lykkesfeldt AE, Martin LA, Dowsett M, Johnston SR: Lapatinib restores hormone sensitivity with differential effects on estrogen receptor signaling in cell models of human epidermal growth factor receptor 2-negative breast cancer with acquired endocrine resistance. Clin Cancer Res 2010, 16:1486-1497.

8. Osborne CK, Neven P, Dirix LY, Mackey JR, Robert J, Underhill C, Schiff R, Gutierrez C, Migliaccio I, Anagnostou VK, Rimm DL, Magill P, Sellers M: Gefitinib or placebo in combination with tamoxifen in patients with hormone receptor-positive metastatic breast cancer: a randomized phase II study. Clin Cancer Res 2011, 17:1147-1159.

9. Hua G, Zhu B, Rosa F, Deblon N, Adélaïde J, Kahn-Perlès B, Birnbaum D, Imbert J: A negative feedback regulatory loop associates the tyrosine kinase receptor ERBB2 and the transcription factor GATA4 in breast cancer cells. Mol Cancer Res 2009, 7:402-414.

10. Soucek L, Whitfield J, Martins CP, Finch AJ, Murphy DJ, Sodir NM, Karnezis AN, Swigart LB, Nasi S, Evan GI: Modelling Myc inhibition as a cancer therapy. Nature 2008, 455:679-683.

11. Johnston SR, Saccani-Jotti G, Smith IE, Salter J, Newby J, Coppen M, Ebbs SR, Dowsett M: Changes in estrogen receptor, progesterone receptor, and pS2 expression in tamoxifen-resistant human breast cancer. Cancer Res 1995, 55:3331-3338.

12. Hiscox S, Morgan L, Barrow D, Dutkowskil C, Wakeling A, Nicholson Rl: Tamoxifen resistance in breast cancer cells is accompanied by an enhanced motile and invasive phenotype: inhibition by gefitinib ('Iressa', ZD1839). Clin Exp Metastasis 2004, 21:201-212.

13. Fan P, Yue W, Wang JP, Aiyar S, Li Y, Kim TH, Santen RJ: Mechanisms of resistance to structurally diverse antiestrogens differ under premenopausal and postmenopausal conditions: evidence from in vitro breast cancer cell models. Endocrinology 2009, 150:2036-2045.

14. Knowlden JM, Hutcheson IR, Jones HE, Madden T, Gee JM, Harper ME, Barrow D, Wakeling AE, Nicholson Rl: Elevated levels of epidermal growth factor receptor/c-erbB2 heterodimers mediate an autocrine growth regulatory pathway in tamoxifen resistant MCF-7 cells. Endocrinology 2003, 144:1032-1044.

15. Fan P, Wang J, Santen RJ, Yue W: Long-term treatment with tamoxifen facilitates translocation of estrogen receptor out of the nucleus and enhances its interaction with EGFR in MCF-7 breast cancer cells. Cancer Res 2007, 67:1352-1360

16. Larsen SS, Egeblad M, Jaattela M, Lykkesfeldt AE: Acquired antiestrogen resistance in MCF-7 human breast cancer sublines is not accomplished by altered expression of receptors in the ErbB-family. Breast Cancer Res Treat 1999, 58:41-56.

17. Berstein LM, Zheng H, Yue W, Wang JP, Lykkesfeldt AE, Naftolin F, Harada $H$, Shanabrough M, Santen RJ: New approaches to the understanding of tamoxifen action and resistance. Endocr Relat Cancer 2003, 10:267-277.

18. Hamburger AW: The human tumor clonogenic assay as a model system in cell biology. Int J Cell Cloning 1987, 5:89-107.

19. Franken NA, Rodermond HM, Stap J, Haveman J, van Bree C: Clonogenic assay of cells in vitro. Nat Protoc 2006, 1:2315-2319.

20. Zimmermann MC, Tilghman SL, Boué SM, Salvo VA, Elliott S, Williams KY, Skripnikova EV, Ashe H, Payton-Stewart F, Vanhoy-Rhodes L, Fonseca JP, Corbitt C, Collins-Burow BM, Howell MH, Lacey M, Shih BY, CarterWientjes C, Cleveland TE, McLachlan JA, Wiese TE, Beckman BS, Burow ME: Glyceollin I, a novel antiestrogenic phytoalexin isolated from activated soy. J Pharmacol Exp Ther 2010, 332:35-45.

21. Schmittgen TD, Zakrajsek BA, Mills AG, Gorn V, Singer MJ, Reed MW: Quantitative reverse transcription-polymerase chain reaction to study mRNA decay: comparison of endpoint and real-time methods. Anal Biochem 2000, 285:194-204.

22. Guo Y, Singleton PA, Rowshan A, Gucek M, Cole RN, Graham DR, Van Eyk JE, Garcia JG: Quantitative proteomics analysis of human endothelial cell membrane rafts: evidence of MARCKS and MRP regulation in the sphingosine 1-phosphate-induced barrier enhancement. Mol Cell Proteomics 2007, 6:689-696.

23. Pierce A, Unwin RD, Evans CA, Griffiths S, Carney L, Zhang L, Jaworska E, Lee CF, Blinco D, Okoniewski MJ, Miller CJ, Bitton DA, Spooncer E, Whetton AD: Eight-channel iTRAQ enables comparison of the activity of six leukemogenic tyrosine kinases. Mol Cell Proteomics 2008, 7:853-863.

24. Tan HT, Tan S, Lin Q, Lim TK, Hew CL, Chung MC: Quantitative and temporal proteome analysis of butyrate-treated colorectal cancer cells. Mol Cell Proteomics 2008, 7:1174-1185.

25. Thomas PD, Campbell MJ, Kejariwal A, Mi H, Karlak B, Daverman R, Diemer K, Muruganujan A, Narechania A: PANTHER: a library of protein families and subfamilies indexed by function. Genome Res 2003, 13:2129-2141.

26. van lersel MP, Kelder T, Pico AR, Hanspers K, Coort S, Conklin BR, Evelo C: Presenting and exploring biological pathways with PathVisio. BMC Bioinformatics 2008, 9:399-407.

27. Pico AR, Kelder T, van lersel MP, Hanspers K, Conklin BR, Evelo C: WikiPathways: pathway editing for the people. PLOS Biol 2008, 6:1403-1407

28. Kanehisa M, Goto S, Hattori M, Aoki-Kinoshita KF, Itoh M, Kawashima S, Katayama T, Araki M, Hirakawa M: From genomics to chemical genomics: new developments in KEGG. Nucleic Acids Res 2006, 34:D354-357.

29. Kanehisa M, Goto S, Furumichi M, Tanabe M, Hirakawa M: KEGG for representation and analysis of molecular networks involving diseases and drugs. Nucleic Acids Res 2010, 38:D355-60.

30. Kanehisa M, Goto S: KEGG: kyoto encyclopedia of genes and genomes. Nucleic Acids Res 2000, 28:27-30

31. Gyorffy B, Lanczky A, Eklund AC, Denkert C, Budczies J, Li Q, Szallasi Z: An online survival analysis tool to rapidly assess the effect of 22,277 genes on breast cancer prognosis using microarray data of 1809 patients. Breast Cancer Res Treatment 2010, 123:725-731.

32. Zhou C, Nitschke AM, Xiong W, Zhang Q, Tang Y, Bloch M, Elliott S, Zhu Y, Bazzone L, Yu D, Weldon CB, Schiff R, McLachlan JA, Beckman BS, Wiese TE, Nephew KP, Shan B, Burow ME, Wang G: Proteomic analysis of tumor necrosis factor-alpha resistant human breast cancer cells reveals a MEK5/Erk5-mediated epithelial-mesenchymal transition phenotype. Breast Cancer Res 2008, 10:R105.

33. Itoh T, Karlsberg K, Kijima I, Yuan YC, Smith D, Ye J, Chen S: Letrozole-, anastrozole-, and tamoxifen-responsive genes in MCF-7aro cells: a microarray approach. Mol Cancer Res 2005, 3:203-218.

34. Cubas R, Zhang S, Li M, Chen C, Yao Q: Trop2 expression contributes to tumor to tumor pathogenesis by activating the ERK MAPK pathway. Mol Cancer 2010, 9:253.

35. Shumay E, Tao J, Wang HY, Malbon CC: Lysophosphatidic acid regulates trafficking of beta2-adrenergic receptors: the Galpha13/p115RhoGEF/JNK pathway stimulates receptor internalization. J Biol Chem 2007, 282:21529-21541.

36. Donato R, Wood SA, Saunders I, Gundsambuu B, Yan Mak K, Abbott CA, Powell BC: Regulation of epithelial apical junctions and barrier function by Galpha13. Biochim Biophys Acta 2009, 1793:1228-1235.

37. Hiramoto-Yamaki N, Takeuchi S, Ueda S, Harada K, Fujimoto S, Negishi M, Katoh H: Ephexin4 and EphA2 mediate cell migration through a RhoGdependent mechanism. J Cell Biol 2010, 190:461-477.

38. Fang WB, Ireton RC, Zhuang G, Takahashi T, Reynolds A, Chen J: Overexpression of EPHA2 receptor destabilizes adherens junctions via a RhoA-dependent mechanism. J Cell Sci 2008, 121:358-368.

39. Kang N, Yaqoob U, Geng Z, Bloch K, Liu C, Gomez T, Billadeau D, Shah V: Focal adhesion assembly in myofibroblasts fosters a microenvironment that promotes tumor growth. Am J Pathol 2010, 177:1888-1900.

40. Borley AC, Hiscox S, Gee J, Smith C, Shaw V, Barrett-Lee P, Nicholson Rl: Anti-oestrogens but not oestrogen deprivation promote cellular invasion in intercellular adhesion-deficient breast cancer cells. Breast Cancer Res 2008, 10:R103

41. Hiscox S, Morgan L, Green TP, Barrow D, Gee J, Nicholson Rl: Elevated Src activity promotes cellular invasion and motility in tamoxifen resistant breast cancer cells. Breast Cancer Res Treat 2006, 97:263-274.

42. Masri S, Phung S, Wang X, Wu X, Yuan YC, Wagman L, Chen S: Genomewide analysis of aromatase inhibitor-resistant, tamoxifen-resistant, and long-term estrogen-deprived cells reveals a role for estrogen receptor. Cancer Res 2008, 68:4910-4918. 
43. Nicholson RI, Staka C, Boyns F, Hutcheson IR, Gee JM: Growth factor driven mechanisms associated with resistance to estrogen deprivation in breast cancer: new opportunities for therapy. Endocr Relat Cancer 2004, 11:623-641.

44. McClelland RA, Barrow D, Madden TA, Dutkowski CM, Pamment J, Knowlden JM, Gee JM, Nicholson Rl: Enhanced epidermal growth factor receptor signaling in MCF-7 breast cancer cells after long-term culture in the presence of the pure antiestrogen ICI 182,780 (Faslodex). Endocrinology 2001, 142:2776-2788.

45. Massarweh S, Osborne CK, Jiang S, Wakeling AE, Rimawi M, Mohsin SK, Hilsenbeck S, Schiff R: Mechanisms of tumor regression and resistance to estrogen deprivation and fulvestrant in a model of estrogen receptorpositive, HER-2/neupositive breast cancer. Cancer Res 2006, 66:8266-8273.

46. Osborne CK, Fuqua SA: Mechanisms of tamoxifen resistance. Breast Cancer Res Treat 1994, 32:49-55.

47. Shou J, Massarweh S, Osborne CK, Wakeling AE, Ali S, Weiss H, Schiff R: Mechanisms of tamoxifen resistance: increased estrogen receptor-HER2/ neu cross-talk in ER/HER2-positive breast cancer. J Natl Cancer Inst 2004, 96:926-935.

48. Gutierrez MC, Detre S, Johnston S, Mohsin SK, Shou J, Allred DC, Schiff R, Osborne CK, Dowsett M: Molecular changes in tamoxifen-resistant breast cancer: relationship between estrogen receptor, HER-2, and p38 mitogen-activated protein kinase. J Clin Oncol 2005, 23:2469-2476.

49. Zilli M, Grassadonia A, Tinari N, Di Giacobbe A, Gildetti S, Giampietro J, Natoli C, lacobelli S, Consorzio Interuniversitario Nazionale per la BioOncologia (CINBO): Molecular mechanisms of endocrine resistance and their implication in the therapy of breast cancer. Biochim Biophys Acta 2009, 1795:62-81.

50. Musgrove EA, Sutherland R: Biological determinants of endocrine resistance in breast cancer. Nat Rev Cancer 2009, 9:631-643.

51. Gee JM, Shaw VE, Hiscox SE, McClelland RA, Rushmere NK, Nicholson Rl: Deciphering antihormone-induced compensatory mechanisms in breast cancer and their therapeutic implications. Endocr Relat Cancer 2006, 13(Suppl 1):S77-88.

52. Nicholson Rl, Hutcheson IR, Jones HE, Hiscox SE, Giles M, Taylor KM, Gee JM: Growth factor signalling in endocrine and anti-growth factor resistant breast cancer. Rev Endocr Metab Disord 2007, 8:241-253.

53. Arpino G, Wiechmann L, Osborne CK, Schiff R: Crosstalk between the estrogen receptor and the HER tyrosine kinase receptor family: molecular mechanism and clinical implications for endocrine therapy resistance. Endocr Rev 2008, 29:217-233.

54. Gururaj AE, Rayala SK, Vadlamudi RK, Kumar R: Novel mechanisms of resistance to endocrine therapy: genomic and nongenomic considerations. Clin Cancer Res 2006, 12:1001s-1007s.

55. Migliaccio A, Castoria G, Giovannelli $P$, Auricchio F: Cross talk between epidermal growth factor (EGF) receptor and extra nuclear steroid receptors in cell lines. Mol Cell Endocrinol 2010, 327:19-24.

56. Arumugam T, Simeone DM, Schmidt AM, Logsdon CD: S100P stimulates cell proliferation and survival via receptor for activated glycation end products (RAGE). J Biol Chem 2004, 279:5059-5065.

57. Arumugam T, Simeone DM, Van Golen K, Logsdon CD: S100P promotes pancreatic cancer growth, survival, and invasion. Clin Cancer Res 2005 11:5356-5364.

58. Fuentes MK, Nigavekar SS, Arumugam T, Logsdon CD, Schmidt AM, Park JC, Huang EH: RAGE activation by S100P in colon cancer stimulates growth, migration, and cell signaling pathways. Dis Colon Rectum 2007, 50:1230-1240.

59. Wärri AM, Huovinen RL, Laine AM, Martikainen PM, Härkönen PL: Apoptosis in toremifene-induced growth inhibition of human breast cancer cells in vivo and in vitro. J Natl Cancer Inst 1993, 85:1412-1418.

60. Chen H, Tritton TR, Kenny N, Absher M, Chiu JF: Tamoxifen induces TGFbeta 1 activity and apoptosis of humanMCF-7 breast cancer cells in vitro. J Cell Biochem 1996, 61:9-17.

61. Redondo M, Téllez T, Roldan MJ, Serrano A, García-Aranda M, Gleave ME, Hortas ML, Morell M: Anticlusterin treatment of breast cancer cells increases the sensitivities of chemotherapy and tamoxifen and counteracts the inhibitory action of dexamethasone on chemotherapyinduced cytotoxicity. Breast Cancer Res 2007, 9:R86.

62. Biroccio A, D'Angelo C, Cansen B, Gleave ME, Zupi G: Antisense clusterin oligodeoxynucleotides increase the response of HER-2 gene amplified breast cancer cells to Trastuzumab. Cell Physiol 2005, 204:463-469.
63. July LV, Akbari M, Zellweger T, Jones EC, Goldenberg SL, Gleave ME: Clusterin expression is significantly enhanced in prostate cancer cells following androgen withdrawal therapy. Prostate 2002, 50:179-188.

64. Zelinski DP, Zantek ND, Stewart JC, Irizarry AR, Kinch MS: EphA2 overexpression causes tumorigenesis of mammary epithelial cells. Cancer Res 2001, 61:2301-2306.

65. Zelinski DP, Zantek ND, Walker-Daniels J, Peters MA, Taparowsky EJ, Kinch MS: Estrogen and Myc negatively regulate expression of the EphA2 tyrosine kinase. J Cell Biochem 2002, 85:714-720.

66. Brantley-Sieders DM, Zhuang G, Hicks D, Fang WB, Hwang Y, Cates JM, Coffman K, Jackson D, Bruckheimer E, Muraoka-Cook RS, Chen J: The receptor tyrosine kinase EphA2 promotes mammary adenocarcinoma tumorigenesis and metastatic progression in mice by amplifying ErbB2 signaling. J Clin Invest 2008, 118:64-78.

67. Lu M, Miller KD, Gokmen-Polar Y, Jeng MH, Kinch MS: EphA2 overexpression decreases estrogen dependence and tamoxifen sensitivity. Cancer Res 2003, 63:3425-3429.

68. Gökmen-Polar Y, Toroni RA, Hocevar BA, Badve S, Zhao Q, Shen C, Bruckheimer E, Kinch MS, Miller KD: Dual targeting of EphA2 and ER restores tamoxifen sensitivity in ER/EphA2-positive breast cancer. Breast Cancer Res Treat 2011, 12:375-384

69. Koltzscher M, Neumann C, Konig S, Gerke V: $\mathrm{Ca}^{2+}$-dependent binding and activation of dormant ezrin by dimeric S100P. Mol Biol Cell 2003, $14: 2372-2384$.

70. Wan X, Kim SY, Guenther LM, Mendoza A, Briggs J, Yeung C, Currier D, Zhang H, Mackall C, Li WJ, Tuan RS, Deyrup AT, Khanna C, Helman L: Beta4 integrin promotes osteosarcoma metastasis and interacts with ezrin. Oncogene 2009, 28:3401-3411.

71. Meng Y, Lu Z, Yu S, Zhang Q, Ma Y, Chen J: Ezrin promotes invasion and metastasis of pancreatic cancer cells. J Transl Med 2010, 8:61.

72. Chen Y, Wang D, Guo Z, Zhao J, Wu B, Deng H, Zhou T, Xiang H, Gao F, Yu X, Liao J, Ward T, Xia P, Emenari C, Ding X, Thompson W, Ma K, Zhu J, Aikhionbare F, Dou K, Cheng SY, Yao X: Rho kinase phosphorylation promotes ezrin-mediated metastasis in hepatocellular carcinoma. Cancer Res 2011, 71:1721-1729.

73. Austermann J, Nazmi AR, Müller-Tidow C, Gerke V: Characterization of the $\mathrm{Ca}^{2+}$-regulated ezrin-S100P interaction and its role in tumor cell migration. J Biol Chem 2008, 283:29331-29340.

74. Heil A, Nazmi AR, Koltzscher M, Poeter M, Austermann J, Assard N, Baudier J, Kaibuchi K, Gerke V: S100P Is a novel interaction partner and regulator of IQGAP1. J Biol Chem 2011, 286:7227-7238.

75. Mataraza JM, Briggs MW, Li Z, Entwistle A, Ridley AJ, Sacks DB: IQGAP1 promotes cell motility and invasion. J Biol Chem 2003, 278:41237-41245.

doi:10.1186/bcr3144

Cite this article as: Zhou et al:: Proteomic analysis of acquired tamoxifen resistance in MCF-7 cells reveals expression signatures associated with enhanced migration. Breast Cancer Research 2012 14:R45.

\section{Submit your next manuscript to BioMed Central and take full advantage of:}

- Convenient online submission

- Thorough peer review

- No space constraints or color figure charges

- Immediate publication on acceptance

- Inclusion in PubMed, CAS, Scopus and Google Scholar

- Research which is freely available for redistribution

Submit your manuscript at www.biomedcentral com/submit
C Biomed Central 